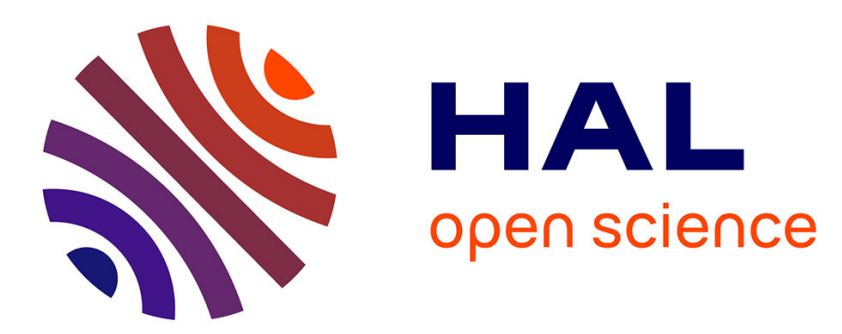

\title{
Bank income structure and risk: An empirical analysis of European banks
}

Laetitia Lepetit, Emmanuelle Nys, Philippe Rous, Amine Tarazi

\section{To cite this version:}

Laetitia Lepetit, Emmanuelle Nys, Philippe Rous, Amine Tarazi. Bank income structure and risk: An empirical analysis of European banks. Journal of Banking and Finance, 2008, 32, pp.1452 - 1467. 10.1016/j.jbankfin.2007.12.002 . hal-01098960

\section{HAL Id: hal-01098960 https://hal.science/hal-01098960}

Submitted on 30 Dec 2014

HAL is a multi-disciplinary open access archive for the deposit and dissemination of scientific research documents, whether they are published or not. The documents may come from teaching and research institutions in France or abroad, or from public or private research centers.
L'archive ouverte pluridisciplinaire HAL, est destinée au dépôt et à la diffusion de documents scientifiques de niveau recherche, publiés ou non, émanant des établissements d'enseignement et de recherche français ou étrangers, des laboratoires publics ou privés. 


\title{
Bank income structure and risk: An empirical analysis of European banks
}

\author{
Laetitia Lepetit, Emmanuelle Nys, Philippe Rous, Amine Tarazi* \\ Université de Limoges, LAPE, 5 rue Félix Eboué, 87031 Limoges Cedex, France
}

November 2007

\begin{abstract}
The purpose of this paper is to investigate the relationship between bank risk and product diversification in the changing structure of the European banking industry. Based on a broad set of European banks for the period 1996-2002, our study first shows that banks expanding into non-interest income activities present higher risk and higher insolvency risk than banks which mainly supply loans. However, considering size effects and splitting non-interest activities into both trading activities and commission and fee activities we show that the positive link with risk is mostly accurate for small banks and essentially driven by commission and fee activities. A higher share of trading activities is never associated with higher risk and for small banks it implies, in some cases, lower asset and default risks.
\end{abstract}

JEL classification: G21

Keywords: bank risk, interest income, non-interest income, product diversification

\footnotetext{
*Corresponding authors: Tel: +33-555-14-92-13, emmanuelle.nys@unilim.fr (E. Nys); laetitia.lepetit@unilim.fr (L. Lepetit); philippe.rous@unilim.fr (P. Rous); amine.tarazi@unilim.fr (A. Tarazi).
} 


\section{Introduction}

In the context of financial deregulation that took place in the seventies and in the eighties, western banking systems faced major changes in the form of increased competition, concentration and restructuring. Banks have reacted to the new environment by adopting a proactive strategy widening the range of products they offer to their clients. These changes mainly implied an increasing share of non-interest income in profits. Non-interest income stems from traditional service charges (checking, cash management, letters of credit...) but also from new sources. With the decline in interest margins induced by higher competition banks were incited to charge higher fees on existing or new services (cash withdrawal, bank account management, data processing...). As a result, the structure of bank income experienced a dramatic change in both the U.S. and Europe. In the eighties, non-interest income represented 19 percent of U.S. commercial banks' total income. This share had grown to 43 percent of total income in 2001 (Stiroh, 2004). In Europe, non-interest income has increased from 26 percent to 41 percent between 1989 and 1998 (ECB, 2000).

With the adoption of the new universal banking principle, commercial banks can compete on a wider range of market segments (investment banking, market trading ...). Numerous studies questioned the implications of this new environment on bank risk. The issue is of importance for the safety and soundness of the banking system and a major challenge for supervisory authorities.

The existing literature, mostly based on U.S. banks, either focused on portfolio diversification effects (risk return profile) (Boyd et al., 1980; Kwan, 1998; De Young and Roland, 2001) or on incentives approaches (Rajan, 1991; John et al., 1994; Puri, 1996; Boyd et al., 1998). Few studies were able to show that the combination of lending and non-interest income activities allows for diversification benefits and therefore risk reduction. Conversely, some papers find a significant positive impact of diversification on earnings volatility (De Young and Roland, 2001; Stiroh, 2004; Stiroh and Rumble, 2006). As noted by De Young and Roland (2001), three main reasons may explain this increase in risk. Firstly, income from lending activities is likely to be relatively stable over time because switching and information costs make it costly for either borrowers or lenders to walk away from a lending relationship. In contrast, income from non-interest income activities may suffer from larger fluctuations as it might be easier to switch banks for this type of activities than for lending. Secondly, expanding non-interest income activities may imply a rise in fixed costs (for example, 
additional staff may be required), which increases the operational leverage of banks. Conversely, once a lending relationship is established, the marginal cost induced by the supply of additional loans is limited to interest expenses. Thirdly, because bank regulators do not require banks to hold capital against non-interest income activities, earnings volatility may increase because of a higher degree of financial leverage. Moreover, as mentioned by Stiroh (2004), cross-selling of different products to a core customer does not imply diversification benefits (more products are sold to the same customer) which may explain why interest income growth and non-interest income growth are highly correlated in his study.

The aim of this paper is to assess the risk implications of the changing structure of the European banking industry which has shifted away from traditional intermediation activities (deposit funded loans) towards activities generating non-interest income. Using individual bank data from 1996 to 2002 for 734 European banks, we start by analysing the link between bank risk and the degree of output diversification measured by three indicators: the income share $\mathrm{i} /$ of non-interest income, ii/ of trading income and iii/ of commissions and fees income. We hence start by comparing the risk level of banks which have expanded into non traditional activities with banks which have not pursued such a strategy. While previous work on bank diversification was essentially dedicated to the U.S. banking industry and mostly on the overall link between risk and portfolio diversification (diversification benefits) we specifically focus on the risk implications of engaging in new commercial activities for European banks. Our results show that higher reliance on non-interest generating activities is associated with higher risk but that higher risk is more strongly correlated with commission and fee income than trading activities. Our findings are more robust for small banks with total assets smaller than 1 billion $€$ which significantly increase their risk exposure when engaging in commission and fee activities. Conversely, for small listed banks a larger share in trading income is associated with a lower risk exposure and lower default risk.

The remainder of the paper is organized as follows. Section 2 reviews the literature on bank risk and product diversification and shows how our study extends the existing work. Section 3 presents our product diversification and risk indicators as well as preliminary univariate tests and section 4 shows the results of our regression analysis. Section 5 concludes. 


\section{Existing literature and research focus}

Over the two past decades, the combination of traditional and non traditional activities in banking has given rise to a substantial number of studies. Most of the existing literature is dedicated to potential diversification benefits for banks to engage in a broader scope of activities. In general, these studies, which essentially considered U.S. data, provide mixed results. For instance, Boyd et al. (1980), who simulated portfolios of banking and non-bank subsidiaries during the 1970s, find a potential for risk reduction at relatively low levels of non-bank activities. The results obtained by Kwast (1989) to determine an optimal riskminimising combination of banking and non-banking activities for the period 1976-1985 show only a slight potential for risk reduction. Gallo et al. (1996) find, over the 1987-1994 period, that combining bank and mutual fund activities allows for some diversification benefits increasing profitability for moderated risk levels ${ }^{1}$.

Another strand of the literature reports no diversification benefits or even an increase in risk when combining traditional and non interest income activities. According to Boyd and Graham (1986), expansion by BHCs into non-bank activities during the seventies tended to increase the risk of failure of banks during the less stringent policy period. Demsetz and Strahan (1997) who study the stock returns of BHCs between 1980 and 1993 find that although banks extended their product mixes, no risk reduction could be observed as banks tended to move to riskier activities and to lower their capital ratio. Kwan (1998), who investigated bank section 20 subsidiaries during the 1990-1997 period, underlines the increased volatility of accounting returns despite a non increase in bank profitability. DeYoung and Roland (2001) look at the impact of fee-based activities on bank profitability and volatility for large U.S. commercial banks from 1988 to 1995 . They conclude that feebased activities, which represent a growing share of banking activities, increase the volatility of bank revenue. A similar result is obtained by Stiroh (2004) who assesses the potential benefit of diversification for US banks engaging in non interest activities for the period 19842001. He shows that net interest income and non interest income (which is relatively more volatile) are increasingly correlated (lower diversification benefits). Stiroh and Rumble (2006) find similar results while considering US financial holding companies for the period 1997-2002.

\footnotetext{
${ }^{1}$ Another group of studies simulate mergers between bank holding companies and nonbank financial firms (Boyd and Graham, 1988; Boyd et al., 1993; Saunders and Walter, 1994; Laderman, 1999; Lown et al. 2000; Allen and Jagtiani, 2000; for a survey, see Kwan and Laderman, 1999). Simulations were ran to assess the impact on risk of combining traditional banking activities and securities and/or insurance activities (US commercial banks were not allowed to provide such activities before 1999).
} 
Several causes were explored to explain why diversification benefits were not effective in some studies. DeYoung and Roland (2001) suggest three explanations: high competition on non-interest income activities, fixed costs associated to fee-based activities and lack of regulation on non-interest income activities. According to Stiroh (2004) and Stiroh and Rumble (2006), as mentioned above, higher correlation between non-interest income and interest income can be due to possible cross-selling of different products to the same customer.

This paper extends the earlier work on bank diversification in several directions. First, to our knowledge, this is the first study to examine the case of the European banking industry which experienced tremendous changes over the last decade ${ }^{2}$. Second, this study considers a large set of risk and insolvency measures based on accounting data but also on market data at the bank individual level. Third, to assess the risk implications of different types of product mixes, non interest generating activities are split into two components: trading activities and commission and fee activities. Fourth, we conduct a regression analysis which enables to capture the major changes in our period of study and we focus on risk implications both for large and small banks which is a major issue regarding diversification.

\section{Definition of variables, data and preliminary statistics}

\subsection{Product diversification variables: an income structure approach}

One way to capture the degree of diversification of bank activities in the literature (see Stiroh (2004)) is to consider the structure of income statements that is the shares of net interest income generated by traditional activities and non-interest income produced by non traditional activities. We therefore define several variables. First, we consider the ratio of net non interest income to net operating income NNII. Net non-interest income is defined as the difference between non-interest income and non-interest expenses; net operating income is the sum of net interest income and net non interest income. Second, our product diversification measure is also disaggregated, as in De Young and Roland (2001) and in Stiroh (2004), to allow for deeper insights. More precisely, we distinguish two components of non-interest income: commission and fee income and trading income. We hence define a ratio of net

\footnotetext{
${ }^{2}$ Acharya, Hasan and Saunders (2002) have studied the case of Italian banks by looking at the degree of diversification of the loan portfolio. Their findings show that loan diversification is not guaranteed to produce a higher return and/or lower risk for banks. Another study (Smith, Staikouras and Wood, 2003) dedicated to European banks focused on the correlation between non-interest income and interest income and their variability showing that the increased importance of non-interest income stabilised profits in the banking industry during the period 1994-1998.
} 
commission and fee income to net operating income (COM) and a ratio of net trading income to net operating income (TRAD). Net commission income is equal to commission income minus commission expense and net trading income is equal to trading income minus trading expense.

\subsection{Accounting data based risk measures}

Three standard measures of risk, based on annual accounting data and determined for each bank throughout the period, are used in our study: (i) the standard deviation of the return on average assets (SDROA); (ii) the standard deviation of the return on average equity (SDROE); (iii) the ratio of loan loss provisions to net loans (LLP).

We also compute insolvency risk measures: (i) the "Z-score" (ADZ) ${ }^{3}$ which indicates the probability of failure of a given bank; (ii) the "ZP-score" (ADZP) as in Goyeau and Tarazi (1992) and its two additive components ${ }^{4}$ which we call $\mathrm{ADZP}_{1}$ and $\mathrm{ADZP}_{2} . \mathrm{ADZP}_{1}$ is a measure of bank portfolio risk whereas $\mathrm{ADZP}_{2}$ is a measure of leverage risk.

\subsection{Market data based risk measures}

To check for robustness, we compute risk and insolvency measures using market data for a sample of listed banks. Three additional risk measures are used which are the standard deviation of weekly stock returns (SDRET) ${ }^{5}$, the market model beta coefficient estimated through a single factor model (BETA) ${ }^{6}$ and specific risk (RSPEC) ${ }^{7}$ which is the standard deviation of the market model residuals. Insolvency risk (bank default risk) is captured using a market data based Z-score ${ }^{8}$ (MDZ) and the distance to default ${ }^{9}$ (DD).

\footnotetext{
${ }^{3} \mathrm{ADZ}=(1+$ average ROE $) /$ SDROE where ROE and SDROE are expressed in percentage. Higher values of Zscores imply lower probabilities of failure (see Boyd and Graham (1986) for details).

${ }^{4} \mathrm{ADZP}=\mathrm{ADZP}_{1}+\mathrm{ADZP}_{2}=\frac{\text { average ROA }}{\mathrm{SDROA}}+\frac{\text { average }(\text { Total equities } / \text { Total assets })}{\text { SDROA }}$.

${ }^{5}$ We use daily stock prices to calculate weekly stock returns. The standard deviation of weekly stock returns at date $t$ is computed over the period $[t-100, t]$.

${ }^{6}$ To calculate the value of the beta at date $t$, we estimate the single index market model over the period [t-100, $\left.t\right]$ using for each country its domestic market return as defined by Datastream International.

${ }^{7}$ We compute for each trading day the single index market model over the period [t-100, $\left.t\right]$. We use the standard deviation of residuals to estimate specific risk at date t.

${ }^{8} \mathrm{MDZ}$-score $=\frac{\overline{\mathrm{R}}+1}{\sigma}$, where $\overline{\mathrm{R}}$ and $\sigma$ are respectively the mean and the standard deviation of the weekly returns $\mathrm{R}_{\mathrm{t}}$ for a given year.
} 


\subsection{Data}

We use a sample consisting of an unbalanced panel of annual report data from 1996 to 2002 for a set of European commercial and cooperative banks established in 14 European $\operatorname{countries}^{10}$ : Austria, Belgium, Denmark, France, Germany, Greece, Italy, Netherlands, Norway, Portugal, Spain, Sweden, Switzerland, United Kingdom (see Appendix, Table A.1). The bank data used for the estimates come from Bankscope Fitch IBCA which is currently the most comprehensive data set for European banks. This database reports information on a number of banks which is almost equivalent to what is officially declared by the European Central Bank (ECB) and is often used by the ECB itself for cross country studies. Apart from the very large number of small German local cooperative banks (more than 1600 banks) that we deliberately ignored, Bankscope reported, at the end of 2002, balance sheets and income statements for 2129 banks for the countries we consider in this study. Considering these 2129 banks we then restricted our sample to 734 banks. First, we deleted 1291 banks with less than three subsequent years of time series observations ${ }^{11}$. Second, in order to minimize the effects of measurement errors we have excluded all the outliers (194 banks) by eliminating the extreme bank/year observations $(2.5 \%$ lowest values and $2.5 \%$ highest values) for each considered variable. We further checked that the statistical properties of our clean sample of 734 banks and the initial sample of 2129 banks were similar by conducting mean tests for all our variables and by performing distribution tests.

Based on the clean sample of 734 banks we also consider a sub-sample of listed banks. Market data (bank stock prices) come from Datastream International. Banks with discontinuously traded stocks being omitted, 156 banks remain in this sub-sample.

\footnotetext{
${ }^{9}$ The distance to default is inferred from the market value of a risky debt (Merton, 1977) based on the Black and Scholes (1973) option pricing formula. Daily market value of the bank's equity come from Datastream. The annual (261 trading days) volatility of the bank's equity is estimated as the standard deviation of the annual moving average of daily equity returns multiplied by $\sqrt{261}$. The maturity of the debt is set to one, i.e. one year. We use the 12 months interbank rates from Datastream for the risk-free rate, except for Greece, for which we use the six-month interbank rate. We obtain data on debt liabilities from Bankscope Ficth IBCA. We calculate the total amount of liabilities as the total amount of deposits, money-market funding, bonds, subordinated debt and hybrid capital.

${ }^{10}$ In Europe, higher competition on traditional intermediation activities has been driving banks to enter into "new" non interest activities. Of course the situation can differ from one country to the other but there has been no recent change in the legal environment regarding universal banking as in the US. The main changes refer to safety and competition (prudential regulation). One could consider the Second EU Banking Directive of 1989 (which has allowed European banks to pursue functional diversification) as a change in the legal environment. However, in some countries banks were already allowed to combine different activities decades ago (Spain, 1974; United Kingdom, 1987...). Historically, German banks were "born" universal and in France banks have, to some extent, always pursued different activities.

${ }^{11}$ All the banks in our sample publish their annual financial statements at the end of the calendar year.
} 
Descriptive statistics of our two samples are presented in Table 1. Both samples show sufficient heterogeneity in different types of banking activities, enabling us to analyse the behaviour of banks depending on their degree of product diversification. To ensure that our sample of 734 banks contains a sufficient number of large and small banks with similar profiles, Table A.2 in Appendix provides descriptive statistics for banks with total assets greater than 1 billion $€$ on average over the period 1996-2002 (366 banks) and banks with total assets smaller than 1 billion $€$ (368 banks). Our criterion for distinguishing large and small banks is similar to Bankscope's and is frequently used in the literature to categorize banks (see Carter and McNulty (2005)). Consistent with the statistics released by the European Central Bank for 2005 (see ECB (2005)), smaller banks in our sample exhibit a lower ROE because they hold a relatively larger amount of equity but their ROA is higher on average. Apart from this difference, the balance sheet profiles and the income shares of noninterest activities are similar on average for large and small banks. The sub-sample of listed banks includes 104 banks with total assets greater than 1 billion $€$ and 52 banks with total assets smaller than 1 billion $€$.

\subsection{Univariate mean tests}

The literature cited above highlights, with regards to U.S. banks, that activity diversification does not necessarily imply lower risk, and may on the contrary increase bank risk. As a first step we check if similar results can also be obtained for European banks by simply conducting mean tests. We therefore split our samples into different panels of banks on the basis of the value of the ratio of net non interest income to net operating income (NNII) We consider as diversified, banks for which the value of the NNII ratio is higher than the third quartile $\left(\mathrm{Q}_{75}\right)$ and as non diversified, banks with a NNII ratio lower than the first quartile $\left(\mathrm{Q}_{25}\right)$. Considering our data, we also compare the level of risk of banks which are characterized by high levels of fee-based activities that is banks with a ratio of net commission income to net operating income (COM) higher than the third quartile $\mathrm{Q}_{75}$, with banks with the same ratio not exceeding the value of the first quartile (COM lower than $\left.\mathrm{Q}_{25}\right)$. Eventually, we undertake the same comparison on the basis of the degree of reliance on trading activities (ratio of net trading income to net operating income (TRAD) higher than $\mathrm{Q}_{75}$ versus $\mathrm{TRAD}$ lower than $\mathrm{Q}_{25}$ ). 


\subsubsection{Bank risk and income structure}

The results in Table 2 show that banks which exhibit high degrees of diversification display higher risk and insolvency measures ${ }^{12}$. Therefore, on the whole, our results obtained for European banks are in line with those underlined for U.S. banks by DeYoung and Roland (2001) and Stiroh (2004). When we focus on the different sources of non traditional income our results also show that greater reliance on fee-based activities is associated with higher risk and higher default (insolvency) risk whereas higher dependence on trading activities does not necessarily imply higher risk levels. The results based on higher frequency market data indicators in Table 3 confirm those obtained with accounting data ${ }^{13}$.

\subsubsection{Income structure and bank characteristics}

In order to further investigate the characteristics of banks in the high non-interest income category and in the low non-interest income category, Table 4 provides mean test results performed on the basis of our different diversification variables. As a whole, banks with a larger income share of non-interest activities are less reliant on traditional intermediation activities (deposit and loans) but are also less leveraged (higher equity ratio). They are also more profitable on average (higher ROE and ROA) and exhibit a higher ratio of personnel expenses to total assets. Banks with a higher income share of trading activities are larger on average, but larger banks do not exhibit a higher or a lower portion of commission and fee income in total income.

\section{Multivariate Regression analysis}

To further investigate this issue on risk and diversification, we conduct in this section cross section OLS estimations on different samples of banks. More precisely, our accounting as well as market based risk measures are regressed on our product diversification variables and a set of control variables as well as country dummies to capture the presence of country specific effects.

\footnotetext{
${ }^{12}$ Similar results, reinforced with higher significance levels, are obtained when the median or the mean is used to discriminate our two sets of banks.

${ }^{13}$ Banks were also ranked on the one hand depending on their average level of diversification and on the other hand given their average risk level over the period 1996-2002. A Spearman test was conducted to compare their respective ranks in each set. The null hypothesis of independency of each group of banks was rejected . In other words, banks with a higher level of risk are also those exhibiting a higher level of diversification (see Tables A.3 and A.4 in appendix).
} 
The estimated models are :

$$
\mathrm{M}_{-} \text {RISK }_{\mathrm{i}}=\alpha+\beta \mathrm{M}_{-} \mathrm{DIV}_{\mathrm{i}}+\sum_{\mathrm{h}=1}^{\mathrm{H}} \gamma_{\mathrm{h}} \mathrm{M}_{-} \mathrm{X}_{\mathrm{hi}}+\operatorname{DUM}_{-} \operatorname{COUNTRY}_{\mathrm{ji}}+\varepsilon_{\mathrm{i}}
$$

where $M_{-}$RISK $_{i}$ is the mean value, for bank $i$, taken for the period 1996-2002, of each market based risk measure (SDRET, RSPEC, BETA, MDZ and DD) and LLP or the value itself of accounting based indicators computed over the sample period (SDROA, SDROE, CVROA, CVROE, ADZ, ADZP, ADZP1, ADZP2).

M_DIV $_{\mathrm{i}}$ is the mean value, for bank $\mathrm{i}$, for the period 1996-2002, of each product diversification variable (NNII, COM and TRAD).

$\mathrm{M} \__{\mathrm{Hi}}$ is the mean value, for bank $\mathrm{i}$, for the period 1996-2002, for a set of control variables $X_{\mathrm{h}}$.

DUM_COUNTRY $\mathrm{ji}_{\mathrm{ji}}$ is a dummy variable which takes the value of one if bank $\mathrm{i}$ belongs to country $\mathrm{j}$ and zero otherwise.

A large set of control variables was initially considered to account for size differences (natural logarithm of total assets $\log (\mathrm{TA})$ ), profitability differences (ROA and ROE), business differences (deposits to total assets (DEP)), loans to total assets (LOANS), personnel expenses to total assets (EXPENSES) and leverage differences (EQUITY). Because of frequent collinearity among the variables both in the large sample and the smaller sample of listed banks, control variables are restricted to $\log (\mathrm{TA}), \mathrm{ROE}$ and the leverage ratio orthogonalized with total assets (OEQUITY) ${ }^{14}$. We also include the annual growth rate of total assets $(\triangle \mathrm{TA})$. An increase in a bank's total assets is presumed to capture the effect on risk of growth strategies and acquisitions experienced by many European banks in the end of the 1990's and the early 2000's. To check for robustness the estimations were also run with alternative sets of control variables. Our results are not altered when the independant variables are all introduced without considering collinearity issues.

Tables 5 and 6 show the results obtained for the whole sample of 734 banks and tables 7 and 8 the results for the sample of 156 listed banks using high frequency market data for risk measures instead of accounting data. For each sample, estimations were also separately

\footnotetext{
$14 \log ($ TA) is strongly and negatively correlated with EQUITY and ROA. Because the leverage ratio is an important determinant of risk, we orthogonalized EQUITY with total assets. Log(TA), LOANS and DEP are positively correlated. For small banks, ROA is negatively correlated with LOANS and DEP but positively correlated for large banks. Our diversification variables NNII, COM and TRAD are strongly and negatively correlated with LOANS but positively correlated with ROA for the small banks included in the large sample of 734 banks.
} 
run for large banks (total assets greater than 1 billion $€$ ) and for small banks (total assets smaller than 1 billion $€)^{15}$. In all our accounting data based estimations (Tables 5 and 6) higher reliance on non-interest activities (measured either by NNII, COM or TRAD) and higher asset growth is associated with an increase in bank default risk (right hand side of the tables). The use of market based indicators confirms the positive impact of asset growth on the probability of failure of banks but the effect of higher reliance on non-interest activities is less clear. An increase in default risk is only induced by a larger share of commission and fee activities at small banks and smaller banks benefit from lower default risk when they further engage in trading activities.

When the dependant variable is a risk indicator (left hand side of the tables) the coefficients associated to the asset growth variable $M_{-} \Delta \mathrm{TA}$ is significant and positive in most of the estimations with higher coefficients and significance levels for market based indicators and specifically for large banks. This result suggests that growth strategies are considered as riskier by market participants and specially for large banks. In our broad samples (large and small banks) an increase in the share of non-interest income is associated with a higher risk but this result is driven by commission and fee income both for listed banks (Table 8) and in the broad sample of banks (Table 6). However, the impact of non-interest activities is different for large and small banks as shown by the estimation results obtained with the subsamples (samples 1', 1', 2', 2" in Tables 5, 6, 7 and 8). Small banks are exposed to higher risk when the income share of commissions and fee activities increases. But small banks might also benefit from lower risk (portfolio diversification effect) for higher shares of trading activities as shown by the results obtained with market based risk indicators (Table 8). Conversely, for large banks, an increase in the share of non-interest activities, either trading or commission and fee activities, does not significantly affect risk although the coefficients of the aggregate variable M_NNII are significant and positive for large listed banks (Table 8). To check for robustness and to explore the effect on risk of a relatively larger expansion into non traditional fee based activities and trading activities we ran our estimations by including dummies for the diversification quartiles $\mathrm{Q}_{75}$ and $\mathrm{Q}_{25}$ instead of the values of COM and TRAD. Tables 9 and 10 show the results respectively for the broad sample and for the sample

\footnotetext{
${ }^{15}$ Country dummy variables were not included in the estimations for these two sub-samples because of an insufficient degree of freedom.
} 
of listed banks ${ }^{16}$. Overall, the main findings regarding the effect of product diversification on bank risk remain the same.

\section{Conclusion}

The objective of this study was to analyze the risk implications of the trend towards stronger product diversification in the European banking industry. Our study shows that banks which have expanded into non-interest income activities present a higher level of risk than banks which mainly perform traditional intermediation activities. A closer investigation shows that this positive relationship between risk and product diversification as measured by bank income structure is more robust for small banks and that, in all cases, risk is mainly positively correlated with the share of fee-based activities but not with trading activities. To some extent, engaging in trading activities might imply a decrease in risk for smaller banks. Therefore the presumption that the diversification benefits of engaging into trading activities might be larger than those induced by supplying services to core customers is not rejected.

\footnotetext{
${ }^{16}$ Results obtained with the diversification quartiles $\mathrm{Q}_{75}$ and $\mathrm{Q}_{25}$ of NNII are not presented in the paper but are available on request.
} 
Table 1. Descriptive statistics for European commercial and cooperative banks, on average over the period 1996-2002 (\%)

$\begin{array}{lllllllllll}\text { LOANS DEP } & \text { EQUITY LLP } & \text { EXPENSES } & \text { ROA } & \text { ROE } & \text { NII } & \text { NNII } & \text { COM } & \text { TRAD } & \text { TA }\end{array}$

Sample 1: Non listed and listed banks (734 banks)

\begin{tabular}{lcccccccccccc} 
Mean & 53.64 & 52.66 & 10.66 & 0.94 & 1.89 & 1.01 & 7.98 & 64.25 & 34.36 & 23.16 & 9.69 & 11361376 \\
Std & 19.83 & 20.01 & 8.76 & 1.16 & 1.86 & 3.45 & 14.12 & 23.80 & 23.98 & 20.28 & 12.28 & 44765822 \\
Max & 96.47 & 90.02 & 59.70 & 9.99 & 24.72 & 30.01 & 77.25 & 100 & 100 & 89.66 & 97.67 & $7.45 \mathrm{E}+08$ \\
Min & 6.91 & 0.61 & 0.49 & -1.67 & 0 & -8.33 & -79.49 & -105.12 & -108.58 & -98.29 & -52.07 & 6084 \\
Sample 2 : Listed banks (156 banks) & & & & & & & & \\
Mean & 64.36 & 59.15 & 8.95 & 0.79 & 2.06 & 1.10 & 11.04 & 66.51 & 33.25 & 26.41 & 5.54 & 44454004 \\
Std & 13.83 & 16.88 & 5.77 & 0.66 & 3.58 & 1.66 & 7.19 & 15.66 & 16.33 & 20.57 & 8.06 & 123687663 \\
Max & 92.12 & 90.96 & 55.00 & 8.00 & 46.59 & 23.53 & 75.77 & 97.09 & 97.22 & 100 & 55.55 & $7.45 \mathrm{E}+08$ \\
Min & 7.81 & 12.92 & 2.23 & -0.54 & 0.26 & -17.54 & -34.89 & 2.78 & -89.55 & -5.67 & -12.16 & 25608 \\
\hline
\end{tabular}

Variable definitions (all variables are expressed in percentage): LOANS = loans/total assets; DEP = deposits/total assets; EQUITY= equity/total assets; $L L P=$ loan loss provisions/net loans; EXPENSES = personnel expenses/total assets; ROA = return on average assets; ROE = return on average equity; $N I I=$ net interest income/net operating income; $C O M=$ net commission income/net operating income; $T R A D=$ net trading income/net operating income; NNII = net non interest income/ net operating income; TA = total assets (thousand euros). 
Table 2. Income structure and accounting indicators of risk for European banks (1996-2002)

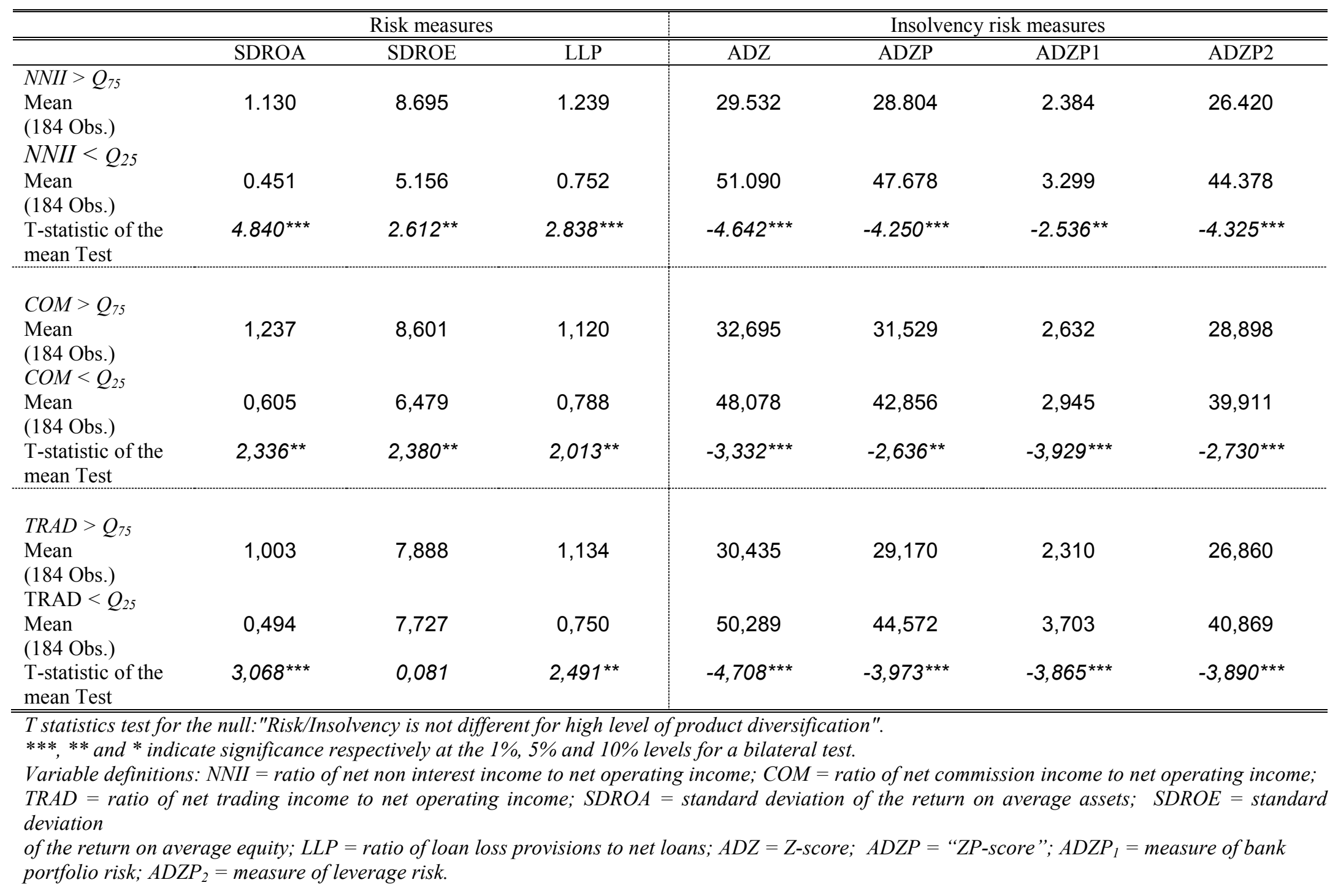


Table 3. Income structure and market indicators of risk for European listed banks (1996-2002)

\begin{tabular}{|c|c|c|c|c|c|}
\hline & \multicolumn{3}{|c|}{ Risk Measures } & \multicolumn{2}{|c|}{ Insolvency risk measures } \\
\hline & SDRET & BETA & RSPEC & MDZ & DD \\
\hline \multicolumn{6}{|l|}{$N N I I>Q_{75}$} \\
\hline $\begin{array}{l}\text { Mean } \\
\text { (Obs.) } \\
N N I I<Q_{25}\end{array}$ & $\begin{array}{c}0.05 \\
39\end{array}$ & $\begin{array}{c}0.66 \\
39\end{array}$ & $\begin{array}{c}0.04 \\
39\end{array}$ & $\begin{array}{c}37.30 \\
39\end{array}$ & $\begin{array}{c}15.51 \\
38\end{array}$ \\
\hline $\begin{array}{l}\text { Mean } \\
\text { (Obs.) } \\
\text { T-statistic of } \\
\text { the mean Test }\end{array}$ & $4.800 * * *$ & $4.970 * * *$ & $3.900 * * *$ & $\begin{array}{c}51.31 \\
39 \\
-2.060^{* *}\end{array}$ & $\begin{array}{c}26.13 \\
38 \\
-1.870^{* *} \\
\end{array}$ \\
\hline$C O M>Q_{75}$ & & & & & \\
\hline $\begin{array}{l}\text { Mean } \\
\text { (Obs.) } \\
\text { COM }<Q_{25}\end{array}$ & $\begin{array}{c}0.05 \\
39\end{array}$ & $\begin{array}{c}0.57 \\
39\end{array}$ & $\begin{array}{c}0.04 \\
39\end{array}$ & $\begin{array}{c}36.15 \\
39\end{array}$ & $\begin{array}{c}15.37 \\
38\end{array}$ \\
\hline $\begin{array}{l}\text { Mean } \\
\text { (Obs.) }\end{array}$ & $\begin{array}{c}0.03 \\
39\end{array}$ & $\begin{array}{c}0.21 \\
39\end{array}$ & $\begin{array}{c}0.03 \\
39\end{array}$ & $\begin{array}{l}55.92 \\
39\end{array}$ & $\begin{array}{c}28.95 \\
38\end{array}$ \\
\hline $\begin{array}{l}\text { T-statistic of } \\
\text { the mean Test }\end{array}$ & $3.270 * * *$ & $3.560 * * *$ & $2.540 * * *$ & $-2.820 * * *$ & $-2.350 * *$ \\
\hline$T R A D>Q_{75}$ & & & & & \\
\hline $\begin{array}{l}\text { Mean } \\
\text { (Obs.) } \\
\text { TRAD }<Q_{25}\end{array}$ & $\begin{array}{c}0.04 \\
34\end{array}$ & $\begin{array}{c}0.68 \\
34\end{array}$ & $\begin{array}{c}0.03 \\
34\end{array}$ & $\begin{array}{c}38.80 \\
34\end{array}$ & $\begin{array}{c}16.09 \\
33\end{array}$ \\
\hline $\begin{array}{l}\text { Mean } \\
\text { (Obs.) } \\
\text { T-statistic of } \\
\text { the mean Test }\end{array}$ & $\begin{array}{c}0.03 \\
34\end{array}$ & $\begin{array}{c}0.32 \\
34\end{array}$ & $\begin{array}{c}0.03 \\
34\end{array}$ & $\begin{array}{c}43.55 \\
34\end{array}$ & $\begin{array}{c}21.29 \\
33\end{array}$ \\
\hline
\end{tabular}

T statistics test for the null: "Risk/Insolvency is not different for highand low degree of product diversification". ***, ** and * indicate significance respectively at the $1 \%, 5 \%$ and $10 \%$ levels for a bilateral test.

Variable definitions: NNII = ratio of net non interest income to net operating income; COM = ratio of net commission income to net operating income; TRAD = ratio of net trading income to net operating income; SDRET = standard deviation of daily stock returns; BETA = market model beta; RSPEC = standard deviation of the market model residual; $M D Z=$ market data based Z-score; $D D=$ distance to default. 
Table 4. Income structure and bank characteristics for European banks (1996-2002)

\begin{tabular}{|c|c|c|c|c|c|c|c|c|c|c|c|}
\hline & LOANS & DEP & EQUITY & EXPENSES & TA & $\mathrm{ROA}$ & ROE & NII & NNII & $\mathrm{COM}$ & TRAD \\
\hline \multicolumn{12}{|l|}{$\overline{N N N I I>Q_{75}}$} \\
\hline Mean & 41.77 & 45.41 & 13.96 & 0.71 & 23821539 & 1.54 & 11.49 & 29.43 & 70.56 & 53.09 & 14.27 \\
\hline (Obs.) & 184 & 184 & 184 & 184 & 184 & 184 & 184 & 184 & 184 & 184 & 184 \\
\hline \multicolumn{12}{|l|}{$N N I I<Q_{25}$} \\
\hline Mean & 66.41 & 56.51 & 10.64 & 0.64 & 3148591 & 0.79 & 7.33 & 85.56 & 14.43 & 12.11 & 1.73 \\
\hline (Obs.) & 184 & 184 & 184 & 184 & 184 & 184 & 184 & 184 & 184 & 184 & 184 \\
\hline $\begin{array}{l}\text { T-statistic of the } \\
\text { mean Test }\end{array}$ & $-15,07 * * *$ & $-6,42 * * *$ & $4,07 * * *$ & $6,93 * * *$ & $3,52 * * *$ & $4,18 * * *$ & $3,17 * * *$ & $-64,08 * * *$ & $61,12 * * *$ & $31,99 * * *$ & $14,12 * * *$ \\
\hline \multicolumn{12}{|l|}{$C O M>Q_{75}$} \\
\hline Mean & 47.16 & 48.83 & 13.16 & 2.90 & 8791319 & 1.47 & 11.58 & 35.90 & 64.09 & 54.89 & 8.39 \\
\hline (Obs.) & 184 & 184 & 184 & 184 & 184 & 184 & 184 & 184 & 184 & 184 & 184 \\
\hline \multicolumn{12}{|l|}{$C O M<Q_{25}$} \\
\hline Mean & 63.50 & 53.87 & 10.32 & 1.10 & 5547763 & 0.81 & 8.00 & 82.28 & 17.71 & 8.55 & 6.36 \\
\hline (Obs.) & 184 & 184 & 184 & 184 & 184 & 184 & 184 & 184 & 184 & 184 & 184 \\
\hline $\begin{array}{l}\text { T-statistic of the } \\
\text { mean Test }\end{array}$ & $-8,66^{* * *}$ & $-2,89 * * *$ & $3,56^{* * *}$ & $7,51 * * *$ & 1,08 & $3,80 * * *$ & $2,75 * * *$ & $-34,02 * * *$ & $31,07 * * *$ & $48,47 * * *$ & $2,22 * *$ \\
\hline \multicolumn{12}{|l|}{$T R A D>Q_{75}$} \\
\hline Mean & 45.58 & 47.16 & 12.16 & 2.05 & 29610494 & 1.26 & 10.65 & 46.28 & 53.71 & 33.46 & 18.41 \\
\hline (Obs.) & 184 & 184 & 184 & 184 & 184 & 184 & 184 & 184 & 184 & 184 & 184 \\
\hline \multicolumn{12}{|l|}{ TRAD $<Q_{25}$} \\
\hline Mean & 65.63 & 56.58 & 9.76 & 1.58 & 5711714 & 0.73 & 8.04 & 74.04 & 25.95 & 25.80 & -1.70 \\
\hline (Obs.) & 184 & 184 & 184 & 184 & 184 & 184 & 184 & 184 & 184 & 184 & 184 \\
\hline $\begin{array}{l}\text { T-statistic of the } \\
\text { mean Test }\end{array}$ & $-11,37 * * *$ & $-4,89 * * *$ & $2,81 * * *$ & $2,19 * *$ & $11,93 * * *$ & $2,90 * * *$ & $1,85^{*}$ & $-13,88^{* * *}$ & $12,15 * * *$ & $3,93 * * *$ & $23,31 * * *$ \\
\hline
\end{tabular}

T statistics test for the null: "bank characteristics are not different for high and low degree of product diversification".

$* * *, * *$ and $*$ indicate significance respectively at the $1 \%, 5 \%$ and $10 \%$ levels for a bilateral test.

Variable definitions: NNII = ratio of net non interest income to net operating income; COM = ratio of net commission income to net operating income; TRAD = ratio of net trading income to net operating income; LOANS = loans/total assets; DEP = deposits/total assets; EQUITY = equity/total assets; EXPENSES = personnel expenses/total assets; $T A=$ total assets (thousand of euros); ROA = return on average assets; $R O E=$ return on average equity; NII = net interest income/net operating income; TA = total assets (thousand euros). 
Table 5. OLS estimations for the sample of 734 banks with M_NNII as the independent variable (cross section estimations)

\begin{tabular}{|c|c|c|c|c|c|c|c|}
\hline & \multicolumn{3}{|c|}{ "Risk measures } & \multicolumn{4}{|c|}{ Insolvency measures } \\
\hline & SDROA & SDROE & M LLP & $\overline{\mathrm{ADZ}}$ & ADZP & ADZP1 & ADZP2 \\
\hline \multicolumn{8}{|c|}{ Sample 1: all banks (734) } \\
\hline $\begin{array}{l}M \_N N I I \\
\text { (t-statistics) }\end{array}$ & $\begin{array}{c}0.0058^{* *} \\
(2.235)\end{array}$ & $\begin{array}{c}0.0859 * * * \\
(2.784)\end{array}$ & $\begin{array}{c}0.0111 * * * \\
(4.157)\end{array}$ & $\begin{array}{c}-0.4389 * * * \\
(-5.919)\end{array}$ & $\begin{array}{c}-0.4231 * * * \\
(-6.406)\end{array}$ & $\begin{array}{c}-0.0222 * * * \\
(-4.202)\end{array}$ & $\begin{array}{c}-0.4008 * * * \\
(-6.494)\end{array}$ \\
\hline M_Log $(T A)$ & $-0.1154 * *$ & $-0.5671 * *$ & $-0.0861 * * *$ & $1.3781 *$ & 1.1725 & $0.1491 * *$ & 1.0233 \\
\hline (t-statistics) & $(-2.116)$ & $(-2.091)$ & $(-3.627)$ & $(1.664)$ & $(1.585)$ & $(2.373)$ & $(1.482)$ \\
\hline$M \_R O E$ & 0.0204 & -0.2147 & $-0.0118^{*}$ & 0.1474 & 0.0731 & $0.0762 * * *$ & -0.0031 \\
\hline (t-statistics) & (1.269) & $(-0.786)$ & $(-1.709)$ & $(1.100)$ & $(0.635)$ & $(4.438)$ & $(-0.029)$ \\
\hline$M \_\Delta T A$ & $0.0007 * * *$ & 0.0004 & $-0.0033 * * *$ & $-0.0206 * * *$ & $-0.0237 * * *$ & $-0.0013 * * *$ & $-0.0224 * * *$ \\
\hline (t-statistics) & $(2.760)$ & $(0.268)$ & $(-3.594)$ & $(-3.247)$ & $(-5.281)$ & $(-4.075)$ & $(-5.269)$ \\
\hline M_OEQUITY & $0.0554 * * *$ & -0.0692 & -0.0021 & 0.0443 & 0.0943 & $-0.0207 * *$ & 0.1150 \\
\hline (t-statistics) & $(4.748)$ & $(-1.206)$ & $(-0.313)$ & $(0.276)$ & $(0.526)$ & $(-2.505)$ & $(0.664)$ \\
\hline $\mathrm{R}^{2}(\%)$ & 23.73 & 7.97 & 17.79 & 10.18 & 12.75 & 14.60 & 13.29 \\
\hline \multicolumn{8}{|c|}{ Sample 1': 368 small banks (total assets smaller than 1 billion $€$ ) } \\
\hline M_NNII & $0.0085^{* *}$ & $0.1154 * * *$ & $0.013 * * *$ & $-0.3964 * * *$ & $-0.3291 * * *$ & $-0.0141 * * *$ & $-0.3149 * * *$ \\
\hline (t-statistics) & $(2.062)$ & $(3.539)$ & $(2.974)$ & $(-5.198)$ & $(-4.470)$ & $(-2.422)$ & $(-4.571)$ \\
\hline M_Log $(T A)$ & -0.1445 & -0.1868 & $-0.2649 * *$ & 1.8863 & 1.0822 & -0.0163 & 1.0982 \\
\hline (t-statistics) & $(-1.104)$ & $(-0.295)$ & $(-2.592)$ & $(0.997)$ & $(0.545)$ & $(-0.126)$ & $(0.583)$ \\
\hline$M R O E$ & 0.0258 & -0.1519 & -0.0152 & 0.1193 & 0.0672 & $0.0634 * * *$ & 0.0037 \\
\hline (t-statistics) & (1.119) & $(-0.612)$ & $(-1.624)$ & $(0.809)$ & $(0.504)$ & $(3.531)$ & $(0.031)$ \\
\hline$M \_\Delta T A$ & $0.0009 * * *$ & 0.0032 & $-0.0045 * * *$ & $-0.0189 * * *$ & $-0.0234 * * *$ & $-0.0013 * * *$ & $-0.022 * * *$ \\
\hline (t-statistics) & (3.419) & $(1.350)$ & $(-3.086)$ & $(-2.824)$ & $(-4.340)$ & $(-2.654)$ & $(-4.460)$ \\
\hline M_OEQUITY & 0.0258 & -0.0742 & 0.0064 & 0.0166 & 0.0953 & -0.0142 & 0.1096 \\
\hline (t-statistics) & (1.119) & $(-1.208)$ & $(0.626)$ & $(0.089)$ & $(0.479)$ & $(-1.194)$ & $(0.579)$ \\
\hline $\mathrm{R}^{2}(\%)$ & 20.90 & 7.30 & 8.78 & 8.55 & 6.01 & 8.56 & 6.53 \\
\hline \multicolumn{8}{|c|}{ Sample 1"': 366 large banks (total assets larger than 1 billion $€$ ) } \\
\hline M_NNII & 0.0008 & 0.0231 & $0.0094 * * *$ & $-0.3558 * * *$ & $-0.3097 * * *$ & $-0.0256 * * *$ & $-0.2841 * * *$ \\
\hline (t-statistics) & $(0.347)$ & $(0.739)$ & $(2.776)$ & $(-3.376)$ & $(-3.901)$ & $(-3.689)$ & $(-3.845)$ \\
\hline M_Log $(T A)$ & -0.0091 & -0.3673 & $-0.0868 * * *$ & -1.7654 & -0.7034 & 0.0974 & -0.8008 \\
\hline (t-statistics) & $(-0.222)$ & $(-0.507)$ & $(-2.861)$ & $(-1.239)$ & $(-0.576)$ & $(0.968)$ & $(-0.699)$ \\
\hline$M \_R O E$ & 0.0087 & -0.3515 & -0.0104 & 0.2104 & 0.0274 & $0.0922 * * *$ & -0.0647 \\
\hline (t-statistics) & $(0.469)$ & $(-0.594)$ & $(-0.882)$ & $(0.834)$ & $(0.133)$ & $(2.967)$ & $(-0.339)$ \\
\hline$M \_\Delta T A$ & -0.0061 & -0.1074 & $-0.0091 * *$ & 0.0549 & 0.0933 & 0.0139 & 0.0793 \\
\hline (t-statistics) & $(-1.100)$ & $(-1.148)$ & $(-2.504)$ & $(0.395)$ & $(0.706)$ & $(1.232)$ & $(0.645)$ \\
\hline M_OEQUITY & $0.0877 * *$ & -0.0423 & -0.0090 & 0.9254 & $1.0644^{*}$ & 0.0058 & $1.0585^{*}$ \\
\hline (t-statistics) & $(2.051)$ & $(-0.152)$ & $(-0.723)$ & $(1.690)^{*}$ & $(1.841)$ & $(0.205)$ & (1.905) \\
\hline $\mathrm{R}^{2}(\%)$ & 25.32 & 5.45 & 9.70 & 5.50 & 7.32 & 12.17 & 7.88 \\
\hline
\end{tabular}

$* * *, * *$ and $*$ indicate significance respectively at the $1 \%, 5 \%$ and $10 \%$ levels. $t$-statistics are corrected for heteroskedasticity following White's methodology. Variable definitions: $M$ X $=$ mean of the variable Xfor bank $i$ over the period 1996-2002; $\log (T A)=$ logarithm of total assets for bank $i ; R O E=$ return on average equity; $\triangle T A=$ annual growth rate of total assets ; OEQUITY = EQUITY orthogonalized with TA; ;NNII = ratio of net non interest income to net operating income; SDROA = standard deviation of the return on average assets; $S D R O E=$ standard deviation of the return on average equity; $L L P=$ ratio of loan loss provisions to net loans; $A D Z=Z$-score; $A D Z P=$ "ZP-score"; $A D Z P_{1}=$ measure of bank portfolio risk; $A D Z P_{2}=$ measure of leverage 
Table 6. OLS estimations for the sample of 734 banks with M_COM and M_TRAD as the independent variables (cross section estimations)

\begin{tabular}{|c|c|c|c|c|c|c|c|}
\hline & \multicolumn{3}{|c|}{ Risk measures } & \multicolumn{4}{|c|}{ Insolvency measures } \\
\hline & SDROA & SDROE & LLP & ADZ & ADZP & ADZP1 & ADZP2 \\
\hline \multicolumn{8}{|c|}{ Sample 1: all banks (734) } \\
\hline$M_{-} \mathrm{COM}$ & 0.0050 & $0.1012 * *$ & $0.0082 * *$ & $-0.4214 * * *$ & $-0.3768 * * *$ & $-0.0172 * *$ & $-0.3596 * * *$ \\
\hline$M T R A D$ & 0.0009 & -0.0130 & 0.0090 & $-0.3003 * *$ & $-0.3666 * * *$ & $-0.223 * *$ & $-0.3443 * * *$ \\
\hline (t-statistics) & $(0.230)$ & $(-0.339)$ & $(1.303)$ & $(-2.307)$ & $(-3.255)$ & $(-2.285)$ & $(-3.300)$ \\
\hline $\mathrm{M} \log (T A)$ & $-0.1105 * *$ & $-0.4701 *$ & $-0.0778 * * *$ & 1.1618 & 1.0240 & $0.1441 * *$ & 0.8798 \\
\hline (t-statistics) & $(-2.073)$ & $(-1.730)$ & $(-3.264)$ & $(1.413)$ & $(1.380)$ & $(2.371)$ & $(1.266)$ \\
\hline$M \_R O E$ & 0.0208 & -0.2208 & -0.0112 & 0.1388 & 0.0524 & $0.0742 * * *$ & -0.0218 \\
\hline (t-statistics) & $(1.286)$ & $(-0.798)$ & $(-1.569)$ & $(1.050)$ & $(0.458)$ & $(4.344)$ & $(-0.210)$ \\
\hline $\begin{array}{l}M \_\Delta T A \\
\text { (t-statistics) }\end{array}$ & $\begin{array}{c}0.0007 * * * \\
(2.982)\end{array}$ & $\begin{array}{l}0.0009 \\
(0.464)\end{array}$ & $\begin{array}{c}-0.0026^{* * *} \\
(-2.770)\end{array}$ & $\begin{array}{c}-0.0225^{* *} \\
(-2.573)\end{array}$ & $\begin{array}{c}-0.025^{* * *} \\
(-4.103)\end{array}$ & $\begin{array}{c}-0.0014 * * * \\
(-3.375)\end{array}$ & $\begin{array}{c}-0.0240 * * * \\
(-4.115)\end{array}$ \\
\hline M_OEQUITY & $0.0561 * * *$ & -0.0572 & -0.0005 & 0.0333 & 0.0936 & $-0.0206^{* *}$ & 0.1143 \\
\hline (t-statistics) & $(4.704)$ & $(-1.010)$ & $(-0.078)$ & $(0.200)$ & $(0.509)$ & $(-2.441)$ & $(0.643)$ \\
\hline $\mathrm{R}^{2}(\%)$ & 23.48 & 7.83 & 16.35 & 9.17 & 11.59 & 13.96 & 12.14 \\
\hline \multicolumn{8}{|c|}{ Sample 1': 368 small banks (total assets smaller than 1 billion $\epsilon$ ) } \\
\hline$M \_C O M$ & $0.0073 *$ & $0.1199 * * *$ & $0.0079 *$ & $-0.3382 * * *$ & $-0.2568 * * *$ & $-0.00944 * *$ & $-0.2474 * * *$ \\
\hline (t-statistics) & (1.913) & $(3.023)$ & $(1.741)$ & $(-3.414)$ & $(-3.056)$ & $(-1.968)$ & $(-3.179)$ \\
\hline$M T R A D$ & 0.0050 & 0.0408 & $0.0347 *$ & $-0.5101 * *$ & $-0.4641 * *$ & -0.0234 & -0.4406 \\
\hline (t-statistics) & $(0.400)$ & $(0.703)$ & $(1.672)$ & $(-2.399)$ & $(-2.152)$ & $(-1.170)$ & $(-2.228)$ \\
\hline M_Log(TA) & -0.1555 & -0.2866 & $-0.2602 * *$ & 2.2667 & 1.4479 & 0.0025 & 1.4454 \\
\hline (t-statistics) & $(-1.198)$ & $(-0.448)$ & $(-2.511)$ & (1.194) & $(0.727)$ & $(0.019)$ & $(0.764)$ \\
\hline$M \_R O E$ & 0.0269 & -0.1493 & -0.0131 & 0.0853 & 0.02633 & $0.0608 * * *$ & -0.0345 \\
\hline (t-statistics) & $(1.172)$ & $(-0.597)$ & $(-1.405)$ & $(0.581)$ & $(0.197)$ & $(3.440)$ & $(-0.278)$ \\
\hline$M \_\Delta T A$ & $0.0009 * * *$ & 0.0035 & $-0.0039 * *$ & $-0.020 * *$ & $-0.0242 * * *$ & $-0.0013^{* *}$ & $-0.0228 * * *$ \\
\hline (t-statistics) & $(3.222)$ & (1.163) & $(-2.582)$ & $(-2.376)$ & $(-3.656)$ & $(-2.413)$ & $(-3.748)$ \\
\hline M_OEQUITY & $0.0624 * * *$ & -0.0671 & 0.0038 & 0.0303 & 0.1040 & -0.0138 & 0.1179 \\
\hline (t-statistics) & (3.499) & $(-1.078)$ & $(0.327)$ & $(0.158)$ & $(0.518)$ & $(-1.140)$ & $(0.618)$ \\
\hline $\mathrm{R}^{2}(\%)$ & 20.53 & 6.63 & 9.38 & 7.65 & 5.14 & 8.21 & 5.63 \\
\hline \multicolumn{8}{|c|}{ Sample 1"': 366 large banks (total assets larger than 1 billion $€$ ) } \\
\hline$M \_C O M$ & -0.0039 & 0.0074 & $0.0088^{*}$ & $-0.3403 * *$ & $-0.2050 *$ & $-0.0185^{* *}$ & $-0.1866^{*}$ \\
\hline (t-statistics) & $(-0.896)$ & $(0.153)$ & $(1.933)$ & $(-2.260)$ & $(-1.910)$ & $(-2.247)$ & $(-1.849)$ \\
\hline$M \_T R A D$ & 0.0029 & -0.0160 & 0.0028 & -0.1427 & $-0.2647 * *$ & $-0.0218 * *$ & $-0.2429 * *$ \\
\hline (t-statistics) & $(1.117)$ & $(-0.307)$ & $(0.587)$ & $(-0.980)$ & $(-2.232)$ & $(-2.026)$ & $(-2.189)$ \\
\hline M_Log $(T A)$ & -0.0145 & -0.2994 & $-0.0689 * *$ & -2.3159 & -0.9076 & 0.0782 & -0.9858 \\
\hline (t-statistics) & $(-0.341)$ & $(-0.401)$ & $(-2.338)$ & $(-1.511)$ & $(-0.709)$ & $(0.743)$ & $(-0.821)$ \\
\hline$M \_R O E$ & 0.0095 & -0.3519 & -0.0108 & 0.2092 & 0.0023 & $0.0906 * * *$ & -0.0882 \\
\hline (t-statistics) & $(0.508)$ & $(-0.591)$ & $(-0.904)$ & $(0.839)$ & $(0.011)$ & $(2.940)$ & $(-0.458)$ \\
\hline$M \_\Delta T A$ & -0.0066 & -0.1038 & $-0.0080 * *$ & 0.0169 & 0.0807 & 0.0127 & 0.0680 \\
\hline (t-statistics) & $(-1.166)$ & $(-1.081)$ & $(-2.339)$ & $(0.114)$ & $(0.583)$ & $(1.085)$ & $(0.527)$ \\
\hline M_OEQUITY & $0.0879 * *$ & -0.0431 & -0.0070 & 0.925 & $1.0576^{*}$ & 0.0048 & $1.0527^{*}$ \\
\hline (t-statistics) & $(2.068)$ & $(-0.155)$ & $(-0.577)$ & (1.639) & $(1.811)$ & $(0.169)$ & (1.877) \\
\hline $\mathrm{R}^{2}(\%)$ & 25.66 & 5.40 & 7.57 & 4.40 & 5.99 & 11.22 & 6.59 \\
\hline
\end{tabular}

$* * *, * *$ and * indicate significance respectively at the 1\%, 5\% and $10 \%$ levels. $t$-statistics are corrected for heteroskedasticity following White's methodology. Variable definitions: $M$ _X mean of the variable Xfor bank $i$ over the period 1996-2002; $\log (T A)=$ logarithm of total assets for bank $i ; R O E=$ return on average equity; $\triangle T A=$ annual growth rate of total assets; OEQUITY = EQUITY orthogonalized with TA; NNII = ratio of net non interest income to net operating income; SDROA = standard deviation of the return on average assets; $S D R O E=$ standard deviation of the return on average equity; CVROA LLP = ratio of loan loss provisions to net loans; $A D Z=Z$-score; $A D Z P=$ "ZP-score"; $A D Z P_{1}=$ measure of bank portfolio risk; $A D Z P_{2}=$ measure of leverage risk. 
Table 7. OLS estimations for the sample of 156 listed banks with M_NNII as the independent variable (cross section estimations)

\begin{tabular}{|c|c|c|c|c|c|}
\hline & \multicolumn{3}{|c|}{ Risk measures } & \multicolumn{2}{|c|}{ Insolvency measures } \\
\hline & SDRET & BETA & RSPEC & MDZ & DD \\
\hline \multicolumn{6}{|c|}{ Sample 2 : 156 listed banks } \\
\hline$M \_N N I I$ & $0.001 * * *$ & $0.010 * * *$ & $0.0006^{* * *}$ & -0.068 & $-0.308 * *$ \\
\hline (t-statistics) & $(3.296)$ & $(3.617)$ & $(2.793)$ & $(-0.258)$ & $(-2.006)$ \\
\hline M_Log $(T A)$ & $0.0001 *$ & $0.0007 * * *$ & 0.0001 & $-0.0006 * * *$ & $-0.0002 * * *$ \\
\hline (t-statistics) & $(1.751)$ & $(4.920)$ & $(0.144)$ & $(-3.634)$ & $(-4.420)$ \\
\hline$M \_R O E$ & -0.0008 & 0.005 & -0.001 & -0.869 & $-0.467 *$ \\
\hline (t-statistics) & $(-0.785)$ & $(0.676)$ & $(-1.516)$ & $(-1.503)$ & $(-1.867)$ \\
\hline$M \_\Delta T A$ & $0.001 * * *$ & $0.011 * * *$ & $0.0005 * * *$ & $-0.854 * * *$ & $-0.383 * * *$ \\
\hline (t-statistics) & $(5.292)$ & $(5.318)$ & $(3.783)$ & $(-4.520)$ & $(-3.230)$ \\
\hline M_OEQUITY & $-0.0006^{*}$ & $-0.013 * * *$ & -0.0009 & 0.563 & $1.646 * * *$ \\
\hline (t-statistics) & $(-1.671)$ & $(-3.222)$ & $(-0.791)$ & $(0.888)$ & $(3.818)$ \\
\hline $\mathrm{R}^{2}(\%)$ & 34.24 & 45.43 & 27.19 & 20.56 & 26.84 \\
\hline \multicolumn{6}{|c|}{ Sample 2': 52 small listed banks (total assets smaller than 1 billion $€$ ) } \\
\hline$M \_N N I I$ & $0.001 *$ & $0.008^{*}$ & $0.001 *$ & 0.259 & -0.597 \\
\hline (t-statistics) & $(1.798)$ & $(1.735)$ & $(1.887)$ & $(0.396)$ & $(-1.257)$ \\
\hline M_Log $(T A)$ & -0.0003 & -0.0001 & -0.0009 & 0.019 & 0.019 \\
\hline (t-statistics) & $(-1.133)$ & $(-0.200)$ & $(-1.139)$ & $(0.909)$ & $(0.703)$ \\
\hline$M \_R O E$ & -0.001 & -0.700 & -0.001 & -0.165 & -1.420 \\
\hline (t-statistics) & $(-1.292)$ & $(-0.753)$ & $(-1.295)$ & $(-0.112)$ & $(-1.163)$ \\
\hline$M \_\Delta T A$ & $0.001 * *$ & $0.008 * *$ & $0.001 *$ & $-1.588 * *$ & -1.061 \\
\hline (t-statistics) & $(2.183)$ & $(2.287)$ & $(1.887)$ & $(-2.609)$ & $(-1.793)$ \\
\hline M_OEQUITY & -0.001 & -0.006 & -0.0008 & -0.429 & $1.960 *$ \\
\hline (t-statistics) & $(-0.859)$ & $(-1.110)$ & $(-0.741)$ & $(-0.392)$ & $(1.766)$ \\
\hline $\mathrm{R}^{2}(\%)$ & 40.58 & 40.21 & 38.67 & 14.40 & 17.41 \\
\hline \multicolumn{6}{|c|}{ Sample 2"': 104 large listed banks (total assets larger than 1 billion $€$ ) } \\
\hline$M \_N N I I$ & $0.0001 * *$ & $0.007^{*}$ & $0.0001 * * *$ & -0.007 & -0.027 \\
\hline (t-statistics) & $(2.612)$ & $(1.924)$ & $(3.379)$ & $(-0.041)$ & $(-0.529)$ \\
\hline M_Log $(T A)$ & 0.0005 & $0.0002 * * *$ & -0.0001 & $-0.0006 * * *$ & $-0.0001 * * *$ \\
\hline (t-statistics) & $(1.378)$ & $(3.576)$ & $(-0.121)$ & $(-3.273)$ & $(-5.112)$ \\
\hline$M \_R O E$ & 0.0008 & 0.0008 & -0.0007 & $-0.812 *$ & $-0.225 * *$ \\
\hline (t-statistics) & $(0.169)$ & $(0.894)$ & $(-0.878)$ & $(-1.788)$ & $(-2.104)$ \\
\hline$M \_\Delta T A$ & $0.001 * * *$ & $0.012 * * *$ & $0.0006^{* * *}$ & $-0.732 * * *$ & $-0.185 * * *$ \\
\hline (t-statistics) & $(4.861)$ & $(4.227)$ & (3.379) & $(-3.992)$ & $(-4.125)$ \\
\hline M_OEQUITY & 0.001 & 0.003 & 0.001 & 0.007 & $0.587 * *$ \\
\hline (t-statistics) & $(0.921)$ & $(0.148)$ & $(1.166)$ & $(0.006)$ & $(2.092)$ \\
\hline$R^{2}(\%)$ & 32.38 & 37.89 & 24.16 & 20.40 & 22.33 \\
\hline
\end{tabular}

$* * *, * *$ and $*$ indicate significance respectively at the $1 \%, 5 \%$ and $10 \%$ levels. -statistics are corrected for heteroskedasticity following White's methodology. Variable definitions: $M X=$ mean of the variable $X$ for bank $i$ over the period 1996-2002; $\log (T A)=$ logarithm of total assets for bank $i$ over the period 1996-2002; ROE = return on average equity; $\triangle T A=$ annual growth rate of total assets; $O E Q U I T Y=$ EQUITY orthogonalized with TA; NNII = ratio of net non interest income to net operating income; SDRET $=$ standard deviation of daily stock returns; BETA $=$ market model beta; RSPEC $=$ standard deviation of the market model residual; $M D Z=$ market data based Z-score; $D D=$ distance to default. 
Table 8. OLS estimations for the sample of 156 listed banks with M_COM and M_TRAD as the independent variables (cross section estimations)

\begin{tabular}{|c|c|c|c|c|c|}
\hline & \multicolumn{3}{|c|}{ Risk measures } & \multicolumn{2}{|c|}{ Insolvency measures } \\
\hline & SDRET & BETA & RSPEC & MDZ & DD \\
\hline \multicolumn{6}{|c|}{ Sample 2 : 156 listed banks } \\
\hline$M \_C O M$ & $0.001 * * *$ & $-0.006 * * *$ & $0.0003 * * *$ & $-0.424 * *$ & -0.486 \\
\hline (t-statistics) & $(4.111)$ & $(-3.322)$ & $(4.208)$ & $(-2.277)$ & $(-1.318)$ \\
\hline$M \_T R A D$ & -0.0001 & -0.006 & -0.0004 & 0.253 & $0.539 *$ \\
\hline (t-statistics) & $(-1.401)$ & $(-0.717)$ & $(-1.358)$ & $(0.469)$ & $(1.720)$ \\
\hline M_Log $(T A)$ & $0.0006^{* * *}$ & $0.0003 * * *$ & $0.0001 * *$ & $-0.0002 * * *$ & $-0.0009 * * *$ \\
\hline (t-statistics) & $(4.233)$ & $(5.769)$ & $(2.635)$ & $(-4.264)$ & $(-5.761)$ \\
\hline$M \_R O E$ & -0.0008 & 0.004 & -0.0006 & -0.766 & $-0.686 * *$ \\
\hline (t-statistics) & $(-0.420)$ & $(0.464)$ & $(-0.742)$ & $(-1.583)$ & $(-2.377)$ \\
\hline$M \_\Delta T A$ & $0.001 * * *$ & $0.014 * * *$ & $0.0007 * * *$ & $-1.009 * * *$ & $-0.662 * * *$ \\
\hline (t-statistics) & $(4.832)$ & $(4.301)$ & $(4.208)$ & $(-4.423)$ & $(-3.335)$ \\
\hline M_OEQUITY & $-0.0007 * * *$ & $-0.016 * * *$ & $-0.0007 * *$ & 0.337 & $2.425 * * *$ \\
\hline (t-statistics) & $(-2.671)$ & $(-4.265)$ & $(-1.983)$ & $(0.832)$ & $(4.462)$ \\
\hline $\mathrm{R}^{2}(\%)$ & 43.96 & 51.04 & 31.23 & 22.69 & 33.55 \\
\hline \multicolumn{6}{|c|}{ Sample 2': 52 small listed banks (total assets smaller than 1 billion $€$ ) } \\
\hline$M \_C O M$ & $0.0006 * * *$ & $0.011 * *$ & $0.0001 * *$ & $-0.112 * *$ & -0.054 \\
\hline (t-statistics) & $(2.947)$ & $(2.405)$ & $(2.382)$ & $(-2.465)$ & $(-0.730)$ \\
\hline$M \_T R A D$ & $-0.001 * * *$ & $-0.011 * * *$ & $-0.001 * * *$ & $4.256^{* * *}$ & $2.980 *$ \\
\hline (t-statistics) & $(-4.403)$ & $(-3.984)$ & $(-4.366)$ & $(4.069)$ & $(1.677)$ \\
\hline M_Log $(T A)$ & 0.0002 & $0.0004 * *$ & -0.0001 & 0.015 & 0.022 \\
\hline (t-statistics) & $(0.074)$ & $(2.039)$ & $(-0.021)$ & $(0.750)$ & $(0.776)$ \\
\hline$M \_R O E$ & -0.0006 & 0.005 & -0.0007 & -0.576 & -2.529 \\
\hline (t-statistics) & $(-0.132)$ & $(1.273)$ & $(-0.104)$ & $(-0.391)$ & $(-1.557)$ \\
\hline$M \_\Delta T A$ & 0.0004 & 0.002 & 0.0006 & -1.136 & $-2.252 * *$ \\
\hline (t-statistics) & $(1.281)$ & $(0.799)$ & $(1.282)$ & $(-1.521)$ & $(-2.284)$ \\
\hline M_OEQUITY & 0.0007 & 0.002 & 0.0003 & -0.242 & 3.345 \\
\hline (t-statistics) & $(1.194)$ & $(0.952)$ & $(1.127)$ & $(-0.302)$ & $(1.627)$ \\
\hline $\mathrm{R}^{2}(\%)$ & 34.49 & 41.99 & 22.26 & 19.53 & 23.77 \\
\hline \multicolumn{6}{|c|}{ Sample 2"': 104 large listed banks (total assets larger than 1 billion $€$ ) } \\
\hline$M \_C O M$ & 0.0001 & -0.0008 & 0.0006 & -0.299 & -1.217 \\
\hline (t-statistics) & $(1.033)$ & $(-0.007)$ & $(1.067)$ & $(-0.691)$ & $(-1.163)$ \\
\hline M_TRAD & -0.0005 & -0.003 & -0.0004 & -0.340 & -0.079 \\
\hline (t-statistics) & $(-0.628)$ & $(-0.316)$ & $(-0.487)$ & $(-0.575)$ & $(-0.413)$ \\
\hline $\mathrm{M} \log (T A)$ & $0.0008 * *$ & $0.0001 * * *$ & 0.0005 & $-0.0008 * *$ & $-0.0008 * * *$ \\
\hline (t-statistics) & $(2.635)$ & $(4.228)$ & $(0.851)$ & $(-2.463)$ & $(-3.903)$ \\
\hline$M \_R O E$ & -0.0009 & 0.005 & -0.0001 & -0.760 & $-0.235^{*}$ \\
\hline (t-statistics) & $(-0.463)$ & $(0.450)$ & $(0.883)$ & $(-1.404)$ & $(-1.727)$ \\
\hline$M \_\Delta T A$ & $0.0001 * * *$ & $0.015 * * *$ & $0.0004 * * *$ & $-0.892 * * *$ & $-0.233 * * *$ \\
\hline (t-statistics) & $(3.659)$ & $(3.589)$ & $(2.890)$ & $(-3.372)$ & $(-3.083)$ \\
\hline M_OEQUITY & 0.0006 & $-0.007 * * *$ & 0.0001 & 0.155 & $0.647^{*}$ \\
\hline (t-statistics) & $(0.017)$ & $(-3.353)$ & $(0.309)$ & $(0.105)$ & $(1.660)$ \\
\hline $\mathrm{R}^{2}(\%)$ & 41.79 & 43.77 & 41.23 & 36.86 & 33.48 \\
\hline
\end{tabular}

$* * *, * *$ and $*$ indicate significance respectively at the $1 \%, 5 \%$ and $10 \%$ levels. $t$-statistics are corrected for heteroskedasticity following White's methodology. Variable definitions: $M_{-} X=$ mean of the variable $X$ for bank $i$ over the period 1996-2002; Log(TA) = logarithm of total assets for bank $i$ over the period 1996-2002; ROE = return on average equity; $\triangle T A=$ annual growth rate of total assets; OEQUITY = EQUITY orthogonalized with TA; NNII = ratio of net non interest income to net operating income; SDRET $=$ standard deviation of daily stock returns; BETA $=$ market model beta; $R S P E C=$ standard deviation of the market model residual; $M D Z=$ market data based Z-score; $D D=$ distance to default. 
Table 9. OLS estimations for the sample of 734 banks with dummies variables on the structure of income as the independent variables (cross section estimations)

\begin{tabular}{|c|c|c|c|c|c|c|c|}
\hline & \multicolumn{3}{|c|}{ Risk measures } & \multicolumn{4}{|c|}{ Insolvency measures } \\
\hline & SDROA & SDROE & LLP & ADZ & ADZP & ADZP1 & ADZP2 \\
\hline \multicolumn{8}{|c|}{ Sample 1 : all banks (734) } \\
\hline D_COMQ75 & $0.247^{*}$ & $3.008 * *$ & 0.061 & $-11.533 * * *$ & $-8.947 * * *$ & $-0.739 * * *$ & $-8.208 * * *$ \\
\hline (t-statistics) & (1.783) & $(2.038)$ & $(0.467)$ & $(-3.597)$ & $(-2.939)$ & $(-3.055)$ & $(-2.874)$ \\
\hline D_COMQ25 & 0.062 & -0.716 & $-0.203^{*}$ & 0.432 & -1.437 & $-0.465^{*}$ & -0.973 \\
\hline (t-statistics) & $(0.548)$ & $(-0.583)$ & $(-1.916)$ & $(0.101)$ & $(-0.416)$ & $(-1.769)$ & $(-0.300)$ \\
\hline D_TRADQ75 & 0.136 & $1.830^{*}$ & 0.183 & $-15.182 * * *$ & $-13.236 * * *$ & $-0.820 * * *$ & $-12.415 * * *$ \\
\hline (t-statistics) & $(0.748)$ & $(1.932)$ & $(1.161)$ & $(-4.939)$ & $(-4.697)$ & $(-4.126)$ & $(-4.669)$ \\
\hline D_TRADQ25 & -0.082 & 2.660 & $-0.200 * *$ & 2.214 & 1.794 & 0.455 & 1.340 \\
\hline (t-statistics) & $(-0.660)$ & $(1.512)$ & $(-2.266)$ & $(0.552)$ & $(0.529)$ & $(1.496)$ & $(0.425)$ \\
\hline M_Log $(T A)$ & $-0.186^{* * *}$ & 0.097 & $-0.109 * * *$ & -0.321 & -0.641 & -0.641 & -0.732 \\
\hline (t-statistics) & $(-4.739)$ & $(0.408)$ & $(-3.987)$ & $(-0.517)$ & $(-1.039)$ & $(-1.039)$ & $(-1.262)$ \\
\hline$M \_R O E$ & 0.021 & -0.214 & -0.010 & 0.090 & -0.001 & $0.075 * * *$ & -0.076 \\
\hline (t-statistics) & $(1.345)$ & $(-0.799)$ & $(-1.363)$ & $(0.676)$ & $(-0.008)$ & $(4.580)$ & $(-0.703)$ \\
\hline$M \_\Delta T A$ & $0.001 * * *$ & 0.001 & $-0.004 * *$ & $-0.020 * *$ & $-0.024 * * *$ & $-0.001 * * *$ & -0.023 \\
\hline (t-statistics) & $(3.952)$ & $(0.205)$ & $(-2.566)$ & $(-2.522)$ & $(-4.298)$ & $(-3.033)$ & $(-0.703)$ \\
\hline M_OEQUITY & $0.059 * * *$ & -0.070 & -0.006 & 0.246 & $0.315^{*}$ & -0.004 & $0.319^{*}$ \\
\hline (t-statistics) & $(4.487)$ & $(-1.119)$ & $(-0.729)$ & $(1.456)$ & (1.715) & $(-0.482)$ & (1.791) \\
\hline \multicolumn{8}{|c|}{$\mathrm{R}^{2}(\%)$} \\
\hline \multicolumn{8}{|c|}{ Sample 1': 368 small banks (total assets smaller than 1 billion $€$ ) } \\
\hline D_COMQ75 & $0.236 * * *$ & $3.461 * *$ & 0.167 & $-10.096^{*}$ & $-4.374 * * *$ & $-0.301 * * *$ & $-4.074 * * *$ \\
\hline (t-statistics) & $(2.842)$ & $(2.029)$ & $(0.590)$ & $(-1.946)$ & $(-3.868)$ & $(-3.730)$ & $(-2.869)$ \\
\hline D_COMQ25 & -0.126 & -1.304 & -0.216 & 6.929 & 4.603 & -0.200 & 4.803 \\
\hline (t-statistics) & $(-0.666)$ & $(-0.957)$ & $(-1.275)$ & (1.169) & $(0.917)$ & $(-0.621)$ & (1.009) \\
\hline D_TRADQ75 & 0.045 & 0.544 & 0.362 & -8.963 & $-9.840 * *$ & -0.487 & $-9.353 * *$ \\
\hline (t-statistics) & $(0.104)$ & $(0.345)$ & $(1.068)$ & $(-1.655)$ & $(-2.064)$ & $(-1.442)$ & $(-2.087)$ \\
\hline D_TRADQ25 & -0.151 & 0.268 & $-0.274^{*}$ & 4.863 & 2.130 & 0.350 & 1.779 \\
\hline (t-statistics) & $(-0.676)$ & $(0.151)$ & $(-1.933)$ & $(0.853)$ & $(0.443)$ & $(0.849)$ & $(0.397)$ \\
\hline M_Log $(T A)$ & -0.195 & 0.621 & $-0.259 * *$ & 2.104 & 0.367 & -0.069 & 0.436 \\
\hline (t-statistics) & $(-1.044)$ & $(0.627)$ & $(-2.324)$ & $(0.820)$ & $(0.158)$ & $(-0.447)$ & $(0.199)$ \\
\hline$M \_R O E$ & $0.043^{*}$ & -0.015 & -0.014 & -0.051 & -0.113 & $0.056 * * *$ & -0.169 \\
\hline (t-statistics) & $(1.815)$ & $(-0.057)$ & $(-1.382)$ & $(-0.307)$ & $(-0.740)$ & $(3.025)$ & $(-1.172)$ \\
\hline$M \_\Delta T A$ & -0.001 & -0.010 & -0.011 & -0.102 & -0.143 & -0.008 & -0.134 \\
\hline (t-statistics) & $(-0.266)$ & $(-0.275)$ & $(-1.430)$ & $(-0.829)$ & $(-1.301)$ & $(-1.077)$ & $(-1.292)$ \\
\hline M_OEQUITY & $0.061 * * *$ & 0.0001 & $-0.017^{*}$ & 0.051 & 0.066 & $-0.023^{* * *}$ & 0.089 \\
\hline (t-statistics) & $(3.606)$ & $(0.004)$ & $(-1.796)$ & $(0.304)$ & $(0.412)$ & $(-2.993)$ & $(0.578)$ \\
\hline \multicolumn{8}{|c|}{$\mathrm{R}^{2}(\%)$} \\
\hline \multicolumn{8}{|c|}{ Sample 1'": 366 large banks (total assets larger than 1 billion $€$ ) } \\
\hline D_COMQ75 & 0.165 & 1.779 & -0.008 & $-11.042 * * *$ & $-11.118 * * *$ & $-1.061 * * *$ & $-10.057 * * *$ \\
\hline (t-statistics) & $(1.642)$ & $(0.870)$ & $(-0.070)$ & $(-2.725)$ & $(-2.989)$ & $(-3.769)$ & $(-2.859)$ \\
\hline D_COMQ25 & 0.261 & 0.190 & -0.204 & -6.146 & $-7.307 * * *$ & -0.675 & -6.632 \\
\hline (t-statistics) & $(2.011)$ & $(0.097)$ & $(-1.601)$ & $(-0.963)$ & $(-4.355)$ & $(-1.609)$ & $(-1.484)$ \\
\hline D_TRADQ75 & $0.173^{*}$ & $2.552 * *$ & 0.018 & $-18.178^{* * *}$ & $-14.654 * * *$ & $-1.163 * * *$ & $-13.491 * * *$ \\
\hline (t-statistics) & (1.959) & $(2.338)$ & $(0.129)$ & $(-4.845)$ & $(-4.355)$ & $(-4.807)$ & $(-4.235)$ \\
\hline$D \_T R A D Q 25$ & -0.015 & 1.742 & -0.097 & -0.076 & 1.480 & 0.557 & 0.923 \\
\hline (t-statistics) & $(-0.156)$ & $(0.706)$ & $(-0.800)$ & $(-0.014)$ & $(0.328)$ & $(-1.298)$ & $(0.222)$ \\
\hline M_Log $(T A)$ & $-0.165 * * *$ & 0.483 & -0.058 & $-3.272 * *$ & $-3.743 * *$ & 0.044 & -3.787 \\
\hline (t-statistics) & $(-3.192)$ & $(0.720)$ & $(-1.396)$ & $(-2.038)$ & $(-2.431)$ & $(0.419)$ & $(-2.585)$ \\
\hline$M \_R O E$ & -0.007 & -0.474 & -0.008 & 0.302 & 0.154 & $0.094 * * *$ & 0.060 \\
\hline (t-statistics) & $(-0.465)$ & $(-0.963)$ & $(-0.679)$ & $(1.418)$ & $(0.847)$ & $(3.456)$ & $(0.362)$ \\
\hline$M \_\Delta T A$ & $0.001 * * *$ & 0.002 & $-0.003 * *$ & $-0.030 * * *$ & $-0.036^{* * *}$ & $-0.001 * * *$ & $-0.034 * * *$ \\
\hline (t-statistics) & $(2.692)$ & $(0.661)$ & $(-2.449)$ & $(-3.029)$ & $(-4.365)$ & $(-2.923)$ & $(-4.359)$ \\
\hline M_OEQUITY & $0.051 * *$ & $-0.308 * *$ & -0.001 & $1.234^{* *}$ & $1.400 * * *$ & $0.039 *$ & 1.361 \\
\hline (t-statistics) & $(2.372)$ & $(-2.076)$ & $(-0.089)$ & $(2.644)$ & $(2.741)$ & $(1.721)$ & $(2.726)$ \\
\hline $\mathrm{R}^{2}(\%)$ & 25.12 & 10.98 & 4.54 & 9.62 & 12.21 & 17.98 & 12.43 \\
\hline
\end{tabular}

$* * *, * *$ and $*$ indicate significance respectively at the $1 \%, 5 \%$ and $10 \%$ levels. $t$-statistics are corrected for heteroskedasticity following White's methodology. Variable definitions: $M \_X=$ mean of the variable $X$ for bank $i$ over the period 1996-2002; $\log (T A)=$ logarithm of total assets for bank $i ; R O E=$ return on average equity; $\triangle T A$ = annual growth rate of total assets; OEQUITY =EQUITY orthogonalized with TA; D_COM/TRADQ75=dummy variable which takes the value of 1 when COM/TRAD for bank $i$ is greater than the third quartile of the overall sample and 0 oterhwise; D_COM/TRADQ25=dummy variable which takes the value of 1 when COM/TRAD for bank $i$ is lower than the first quartile of the overall sample and 0 oterhwise; SDROE = standard deviation of the return on average equity; CVROA LLP = ratio of loan loss provisions to net loans; $A D Z=Z$-score; $A D Z P=$ "ZP-score"; $A D Z P_{1}=$ measure of bank portfolio risk; $A D Z P_{2}=$ measure of leverage risk. 
Table 10. OLS estimations for the sample of 156 listed banks with dummies variables on the structure of income as the independent variables (cross section estimations)

\begin{tabular}{|c|c|c|c|c|c|}
\hline & \multicolumn{3}{|c|}{ Risk measures } & \multicolumn{2}{|c|}{ Insolvency measures } \\
\hline & SDRET & BETA & RSPEC & MDZ & $\mathrm{DD}$ \\
\hline \multicolumn{6}{|c|}{ Sample 2: 156 listed banks } \\
\hline D_COMQ75 & $0.008 * *$ & 0.091 & $0.006^{* *}$ & -9.649 & $-6.468 * *$ \\
\hline (t-statistics) & $(2.047)$ & $(0.832)$ & $(2.020)$ & $(-1.594)$ & $(-2.257)$ \\
\hline D_COMQ25 & -0.003 & $-0.118 * *$ & -0.002 & -2.987 & 4.119 \\
\hline (t-statistics) & $(-1.289)$ & $(-2.131)$ & $(-1.009)$ & $(-0.510)$ & $(0.760)$ \\
\hline D_TRADQ75 & 0.004 & $0.164 *$ & 0.003 & -9.596 & 4.062 \\
\hline (t-statistics) & $(1.341)$ & $(1.803)$ & $(1.212)$ & $(-1.478)$ & $(0.881)$ \\
\hline D_TRADQ25 & 0.004 & 0.080 & 0.004 & $-10.610 * *$ & -1.563 \\
\hline (t-statistics) & $(1.262)$ & $(1.059)$ & $(1.447)$ & $(-1.969)$ & $(-0.270)$ \\
\hline M_Log $(T A)$ & $0.0001 * * *$ & $0.0007 * * *$ & $0.0005 *$ & $-0.0008 * * *$ & $-0.0003 * * *$ \\
\hline (t-statistics) & $(3.285)$ & $(5.223)$ & $(1.841)$ & $(-3.449)$ & $(-5.332)$ \\
\hline$M \_R O E$ & -0.0005 & 0.005 & -0.0001 & $-0.945^{*}$ & $-0.682 * *$ \\
\hline (t-statistics) & $(-0.179)$ & $(0.463)$ & $(-0.488)$ & $(-1.799)$ & $(-2.261)$ \\
\hline$M \_\Delta T A$ & $0.0006^{* * *}$ & $0.012 * * *$ & $0.0002 * * *$ & $-0.935 * * *$ & $-0.609 * * *$ \\
\hline (t-statistics) & (3.839) & $(3.732)$ & $(2.976)$ & $(-3.905)$ & $(-2.932)$ \\
\hline M_OEQUITY & -0.0007 & -0.005 & 0.0003 & 0.110 & $2.255 * * *$ \\
\hline (t-statistics) & $(-0.103)$ & $(-1.135)$ & $(0.242)$ & $(0.306)$ & $(3.362)$ \\
\hline $\mathrm{R}^{2}(\%)$ & 34.13 & 45.55 & 21.34 & 24.35 & 29.49 \\
\hline \multicolumn{6}{|c|}{ Sample 2': 52 small listed banks (total assets smaller than 1 billion $€$ ) } \\
\hline D_COMQ75 & $0.008 * *$ & -0.038 & $0.008 * *$ & $-28.868 * *$ & $-34.487 *$ \\
\hline (t-statistics) & $(2.199)$ & $(-0.991)$ & $(2.306)$ & $(-2.258)$ & $(-1.647)$ \\
\hline D_COMQ25 & 0.002 & 0.019 & 0.002 & -5.391 & -0.401 \\
\hline (t-statistics) & $(0.956)$ & $(0.783)$ & $(0.952)$ & $(-0.685)$ & $(-0.040)$ \\
\hline D_TRADQ75 & $-0.006 * * *$ & $-0.035 * * *$ & $-0.006 * * *$ & $23.353 * *$ & $28.292 * *$ \\
\hline (t-statistics) & $(-2.954)$ & $(-2.865)$ & $(-2.962)$ & $(2.383)$ & $(2.167)$ \\
\hline$D_{-} T R A D Q 25$ & 0.003 & 0.019 & 0.003 & $-14.225^{*}$ & 4.514 \\
\hline (t-statistics) & $(1.250)$ & $(0.557)$ & $(1.274)$ & $(-1.736)$ & $(0.220)$ \\
\hline M_Log $(T A)$ & -0.0006 & $0.0001 * *$ & -0.0008 & 0.019 & 0.020 \\
\hline (t-statistics) & $(-0.098)$ & $(2.074)$ & $(-0.201)$ & $(0.886)$ & $(0.569)$ \\
\hline$M \_R O E$ & 0.0007 & 0.003 & 0.0002 & -1.011 & -2.837 \\
\hline (t-statistics) & $(0.128)$ & $(0.708)$ & $(0.167)$ & $(-0.615)$ & $(-1.297)$ \\
\hline$M \_\Delta T A$ & 0.0009 & 0.001 & 0.0003 & -0.988 & $-1.958 * *$ \\
\hline (t-statistics) & $(1.049)$ & $(0.553)$ & (1.044) & $(-1.211)$ & $(-1.996)$ \\
\hline M_OEQUITY & 0.0003 & $0.004 *$ & 0.0002 & 0.021 & $2.848^{* *}$ \\
\hline (t-statistics) & $(1.356)$ & $(1.859)$ & $(1.266)$ & $(0.032)$ & $(2.365)$ \\
\hline $\mathrm{R}^{2}(\%)$ & 40.78 & 39.32 & 40.56 & 37.10 & 31.99 \\
\hline \multicolumn{6}{|c|}{ Sample 2"': 104 large listed banks (total assets larger than 1 billion $€$ ) } \\
\hline D_COMQ75 & 0.005 & 0.027 & 0.004 & -5.390 & -1.221 \\
\hline (t-statistics) & $(1.343)$ & $(0.255)$ & $(1.282)$ & $(-0.855)$ & $(-0.604)$ \\
\hline D_COMQ25 & 0.001 & -0.038 & 0.001 & $-12.080 *$ & -3.321 \\
\hline (t-statistics) & $(0.354)$ & $(-0.479)$ & $(0.538)$ & $(-1.787)$ & $(-1.570)$ \\
\hline$D \_T R A D Q 75$ & $0.007^{*}$ & $0.222 * *$ & $0.005^{*}$ & $-15.184 * *$ & $-4.488^{* *}$ \\
\hline (t-statistics) & $(1.884)$ & $(1.990)$ & (1.869) & $(-2.205)$ & $(-2.293)$ \\
\hline D_TRADQ 25 & -0.001 & -0.025 & 0.001 & -3.205 & 0.293 \\
\hline (t-statistics) & $(-0.146)$ & $(-0.235)$ & $(0.272)$ & $(-0.480)$ & $(0.133)$ \\
\hline M_Log $(T A)$ & 0.0002 & $0.0001 * * *$ & -0.0005 & $-0.0004 * *$ & $-0.0002 * * *$ \\
\hline (t-statistics) & $(1.283)$ & $(2.669)$ & $(-0.001)$ & $(-2.051)$ & $(-3.299)$ \\
\hline$M \_R O E$ & -0.0001 & 0.004 & -0.0003 & -0.890 & $-0.264 *$ \\
\hline (t-statistics) & $(-0.417)$ & $(0.344)$ & $(-0.791)$ & $(-1.576)$ & $(-1.877)$ \\
\hline$M \_\Delta T A$ & $0.0003 * * *$ & $0.012 * * *$ & $0.0004^{*}$ & $-0.823 * * *$ & $-0.212 * * *$ \\
\hline (t-statistics) & $(2.879)$ & $(3.114)$ & $(1.893)$ & $(-3.168)$ & $(-2.837)$ \\
\hline M_OEQUITY & 0.001 & 0.022 & 0.001 & -0.313 & 0.381 \\
\hline (t-statistics) & $(0.927)$ & $(0.738)$ & $(0.928)$ & $(-0.239)$ & (1.069) \\
\hline $\mathrm{R}^{2}(\%)$ & 30.24 & 40.45 & 18.52 & 25.43 & 28.76 \\
\hline
\end{tabular}

$* * *, * *$ and $*$ indicate significance respectively at the $1 \%, 5 \%$ and $10 \%$ levels. $t$-statistics are corrected for heteroskedasticity following White's methodology. Variable definitions: $M$ X $=$ mean of the variable $X$ for bank $i$ over the period 1996-2002; Log(TA) = logarithm of total assets for bank $i$ over the period 19962002; $R O E=$ return on average equity; $\triangle T A=$ annual growth rate of total assets; OEQUITY $=$ EQUITY orthogonalized with TA; ; D_COM/TRADQ75= dummy variable which takes the value of 1 when COM/TRAD for bank $i$ is greater than the third quartile of the overall sample and 0 oterhwise; D_COM/TRADQ25= dummy variable which takes the value of 1 when COM/TRAD for bank $i$ is lower than the first quartile of the overall sample and 0 oterhwise; ; SDRET = standard deviation of daily stock returns; BETA = market model beta; $R S P E C=$ standard deviation of the market model residual; $M D Z=$ market data based Z-score: $D D=$ distance to default. 


\section{References}

Acharya, V., Hasan, I., Saunders, A., 2002. The effects of focus and diversification on bank risk and return: evidence from individual bank loan portfolio.CEPR Discussion Paper $n^{\circ} 3252$. Allen, L., Jagtiani, J., 2000. The risk effect of combining banking, securities and insurance activities. Journal of Economics and Business 52(6), 485-497.

Black F., Scholes M., 1973. The pricing options and corporate liabilities. Journal of Political Economy, 637-654.

Boyd, J., Chang, C., Smith, D., 1998. Moral hazard under commercial and universal banking. Journal of Money, Credit and Banking 30(3).

Boyd, J., Graham, S., 1986. Risk, regulation, and bank holding company expansion. Federal Reserve Bank of Mineapolis, Quaterly Review, spring.

Boyd, J., Graham, G., 1988. The profitability and risk effects of allowing bank holding companies to merge with other financial firms: a simulation study. Federal Reserve Bank of Minneapolis, Quaterly Review, spring.

Boyd, J., Graham, G., Hewitt, R., 1993. Bank holding company mergers with nonblank financial firms, Journal of Banking and Finance 17, 43-63.

Boyd, J., Hanweck, G., Pithyachariyakul, P., 1980. Bank holding company diversification. Federal Reserve Bank of Chicago, Proceedings from a conference on Bank Structure and Competition, May, 105-120.

Carter, D., McNulty, J., 2005. Deregulation, Technological Change, and the BusinessLending Performance of Large and Small Banks, Journal of Banking and Finance 29, 11131130.

Demsetz, R., Strahan, P., 1997. Diversification, size, and risk at Bank Holding Companies. Journal of Money, Credit and Banking 29(3), 300-313.

De Young, R., Roland, K., 2001. Product mix and earnings volatility at commercial banks: Evidence from a degree of total leverage model. Journal of Financial Intermediation 10, 5484.

European Central Bank, 2005. EU Banking Sector Stability, October.

European Central Bank, 2000. EU banks' income structure. Banking Supervision Committee, April.

Gallo, J., Apilado, V., Kolari, J., 1996. Commercial bank mutual fund activities: implications for bank risk and profitability. Journal of Banking and Finance 20, 1775-1791. 
Goyeau, D., Tarazi, A., 1992. Evaluation du risque de défaillance bancaire en Europe, Revue d'Economie Politique 102 (2), 249-280.

John K., John, T.A., Saunders, A., 1994, Universal banking and firm risk-taking. Journal of Banking and Finance 18(2), 307-323.

Kwan, S., 1998. Securities activities by commercial banking firms' section 20 subsidiaries: risk, return and diversification benefits. Economic Research, Federal Reserve Bank of San Francisco.

Kwan, S., Laderman, E., 1999. On the portfolio effects of financial convergence: a review of the literature. Federal Reserve Bank of San Francisco, Economic Review 2, 18- 31.

Kwast, M., 1989. The impact of underwriting and dealing on bank returns and risks. Journal of Banking and Finance 13, 101-125.

Laderman, E., 1999. The potential diversification and failure reduction benefits of bank expansion into nonbanking activities. Economic Research, Federal Reserve Bank of San Francisco.

Lown, C., Osler, C., Strahan, P., Sufi, A., 2000. The changing landscape of the financial service industry: what lies ahead? Economic Policy Review, Federal Reserve Bank of New York. October, 39-54.

Merton R.C., 1977. On the pricing of contingent claims and the Modigliani-Miller theorem. Journal of Financial Economics (5), 241-249.

Puri, M., 1996. Conflicts of interest, intermediation, and the pricing of underwritten securities. Mimeo, Graduate School of Business, Stanford University, Mars.

Rajan, R., 1991. Conflict of interest and the separation of commercial and investment banking. Working Paper, University of Chicago.

Saunder, A., Walter, I., 1994, Universal banking in the United States: What could we gain ? What could we lose? New York: Oxford University Press.

Smith, R., Staikouras, C., Wood, G., 2003. Non-interest income and total income stability.Working Paper $n^{\circ} 198$ - Bank of England.

Stiroh, K., 2004. Diversification in banking: Is non-interest income the answer? Journal of Money, Credit and Banking 36(5), 853-882.

Stiroh, K., Rumble, A., 2006. The dark side of diversification: The case of US financial holding companies. Journal of Banking and Finance, 30(8), 2131-2161. 


\section{Appendix}

Table A.1. Distribution of banks by country

\begin{tabular}{|l|ccc|c|}
\hline \multirow{2}{*}{ Austria } & \multicolumn{3}{|c|}{ Non listed and listed banks } & \multirow{2}{*}{ Listed banks } \\
\cline { 2 - 5 } Belgium & All banks & Large banks & Small banks & 4 \\
Denmark & 29 & 9 & 20 & 1 \\
France & 21 & 11 & 10 & 33 \\
Germany & 43 & 7 & 36 & 23 \\
Greece & 160 & 108 & 52 & 16 \\
Italy & 16 & 16 & 0 & 9 \\
Netherlands & 9 & 9 & 0 & 26 \\
Norway & 152 & 69 & 83 & 1 \\
Portugal & 28 & 20 & 8 & 15 \\
Spain & 15 & 10 & 5 & 3 \\
Sweden & 17 & 12 & 5 & 12 \\
Switzerland & 59 & 27 & 32 & 3 \\
United Kingdom & 6 & 6 & 0 & 6 \\
\hline Total & 70 & 15 & 94 & 4 \\
\hline
\end{tabular}


Table A.2. Descriptive statistics for large and small European commercial and cooperative banks, on average over the period 1996-2002 (\%)

$\begin{array}{llllllllll}\text { LOANS DEP EQUITY LLP } & \text { EXPENSES ROA } & \text { ROE } & \text { NII } & \text { NNII } & \text { COM } & \text { TRAD } & \text { TA }\end{array}$

\begin{tabular}{|c|c|c|c|c|c|c|c|c|c|c|c|c|}
\hline \multicolumn{13}{|c|}{ Large banks $T A>1$ billion } \\
\hline \multicolumn{13}{|c|}{ Sample 1: Non listed and listed banks (366 banks) } \\
\hline Mean & 54.50 & 50.48 & 6.74 & 0.79 & 1.42 & 0.56 & 8.38 & 65.57 & 32.18 & 20.91 & 9.025 & 23117349 \\
\hline Std & 18.59 & 19.19 & 4.51 & 0.84 & 0.76 & 0.71 & 10.87 & 20.87 & 20.57 & 16.15 & 12.76 & 62346854 \\
\hline Max & 95.49 & 83.67 & 51.42 & 6.77 & 3.82 & 3.92 & 38.01 & 100 & 93.91 & 86.22 & 92.79 & $7.45 \mathrm{E}+08$ \\
\hline Min & 10.53 & 2.41 & 0.49 & -0.89 & 0.03 & -7.10 & -114.52 & -105.12 & -108.58 & -98.29 & -52.07 & 1019069 \\
\hline \multicolumn{13}{|c|}{ Sample 2 : Listed banks (104 banks) } \\
\hline Mean & 61.57 & 71.19 & 7.14 & 0.77 & 1.49 & 0.662 & 9.628 & 69.59 & 38.64 & 29.24 & 5.51 & 66504527 \\
\hline Std & 17.88 & 11.63 & 3.01 & 0.49 & 0.51 & 0.964 & 9.27 & 11.31 & 14.67 & 11.75 & 6.09 & 146796957 \\
\hline Max & 92.12 & 88.19 & 17.51 & 2.52 & 2.72 & 3.67 & 75.77 & 97.09 & 84.24 & 82.02 & 25.94 & $7.45 \mathrm{E}+08$ \\
\hline Min & 7.81 & 43.91 & 2.23 & -0.07 & 0.26 & -6.58 & -34.89 & 25.61 & -89.55 & -2.81 & -9.33 & 1065437 \\
\hline
\end{tabular}

\section{Small banks $T A<1$ billion}

Sample 1: Non listed and listed banks (368 banks)

\begin{tabular}{lcccccccccccc} 
Mean & 52.71 & 54.66 & 14.42 & 1.09 & 2.34 & 1.41 & 7.59 & 63.04 & 36.38 & 25.26 & 10.29 & 378399 \\
Std & 21.11 & 20.56 & 10.11 & 1.41 & 2.41 & 4.72 & 16.60 & 26.18 & 26.63 & 23.32 & 11.83 & 263 \\
Max & 96.47 & 90.02 & 59.70 & 9.99 & 24.72 & 30.01 & 77.25 & 100 & 100 & 89.66 & 97.67 & 999783 \\
Min & 6.91 & 0.61 & 0.49 & -1.67 & 0 & -8.33 & -79.49 & 0 & -38.03 & -55.63 & -24.58 & 6084 \\
Sample & $2:$ Listed banks (52 banks) & & & & & & & & & \\
Mean & 58.90 & 72.74 & 16.90 & 1.31 & 2.88 & 1.28 & 8.91 & 73.06 & 34.50 & 22.57 & 4.56 & 352958 \\
Std & 24.64 & 19.38 & 14.48 & 1.34 & 3.61 & 3.56 & 7.42 & 14.59 & 26.48 & 19.14 & 13.67 & 273529 \\
Max & 90.42 & 90.96 & 55.00 & 8.00 & 46.59 & 23.53 & 23.47 & 87.91 & 97.22 & 100 & 55.55 & 993219 \\
Min & 11.16 & 12.92 & 4.35 & -0.54 & 0.82 & -17.54 & -29.08 & 2.78 & -0.09 & -5.67 & -12.16 & 25608 \\
\hline
\end{tabular}

Variable definitions (all variables are expressed in percentage): LOANS = loans/total assets; DEP = deposits/total assets; EQUITY= equity/total assets; LLP = loan loss provisions/net loans; EXPENSES = personnel expenses/total assets; ROA = return on average assets; $R O E=$ return on average equity; $N I I=$ net interest income/net operating income; $C O M=$ net commission income/net operating income; $T R A D=$ net trading income/net operating income; $N N I I=$ net non interest income/ net operating income; MARGIN = net interest income/total earning assets; Interest revenue = Interest revenue/total earning assets; Lending rate = Interest on loans/net loans; TA = total assets (thousand euros). 
Table A.3. Rank correlation test: product diversification and level of risk and insolvency measures for European banks (1996-2002)

\begin{tabular}{|c|c|c|c|c|c|c|c|}
\hline & \multicolumn{3}{|c|}{ Risk Measures } & \multicolumn{4}{|c|}{ Insolvency measures } \\
\hline & SDROA & SDROE & LLP & $\mathrm{ADZ}$ & ADZP & ADZP1 & ADZP2 \\
\hline \multicolumn{8}{|l|}{$N N I I$} \\
\hline $\begin{array}{l}\text { \% Rank Cor. } \\
\text { Spearman }\end{array}$ & 29.28 & 28.43 & 2.87 & 655.9 & -27.28 & -15.59 & -27.95 \\
\hline Stat. & 9 & 8.74 & 0.86 & -201 & -8.39 & -4.80 & -8.60 \\
\hline $\begin{array}{l}\text { Significance } \\
\text { level }(\%)\end{array}$ & $0.00 * * *$ & $0.00 * * *$ & 39.08 & $0.00 * * *$ & $0.00 * * *$ & $0.00 * * *$ & $0.00 * * *$ \\
\hline \multicolumn{8}{|l|}{$C O M$} \\
\hline $\begin{array}{l}\text { \% Rank Cor. } \\
\text { Spearman }\end{array}$ & 22.25 & 18.57 & 1.80 & -804 & -16.38 & -7.85 & -17.01 \\
\hline & 6.81 & 5.69 & 0.54 & -247 & -5.01 & -2.40 & -5.21 \\
\hline level $(\%)$ & $0.00 * * *$ & $0.00 * * *$ & 59.05 & $0.000 * * *$ & $0.00 * * *$ & $1.63 * *$ & $0.00 * * *$ \\
\hline \multicolumn{8}{|l|}{$T R A D$} \\
\hline $\begin{array}{l}\text { \% Rank Cor. } \\
\text { Spearman }\end{array}$ & 17.69 & 18.97 & 6.82 & -551 & -17.78 & -13.07 & -17.73 \\
\hline $\begin{array}{l}\text { Stat. } \\
\text { Significance }\end{array}$ & 4.71 & 5.05 & 1.77 & -168.7 & -4.73 & -3.48 & -4.72 \\
\hline level $(\%)$ & $0.00 * * *$ & $0.00 * * *$ & $7.72 *$ & $0.000 * * *$ & $0.00 * * *$ & $0.05 * * *$ & $0.00 * * *$ \\
\hline \multicolumn{8}{|c|}{$\begin{array}{l}\text { T statistics test for the null:"Risk/Insolvency is not higher for high level of product } \\
\text { diversification". } \\
\text { ***, ** and * indicate significance respectively at the } 1 \% \text {, 5\% and } 10 \% \text { levels for a } \\
\text { unilateral test. } \\
\text { Variable definitions: NNII = ratio of net non interest income to net operating income; COM } \\
=\text { ratio of net commission income to net operating income; TRAD = ratio of net trading } \\
\text { income to net operating income; SDROA = standard deviation of the return on average } \\
\text { assets; SDROE = standard deviation of the return on average equity; CVROA = coefficient } \\
\text { of variation of the return on average assets; CVROE = coefficient of variation of the return } \\
\text { on average equity; } L L P=\text { ratio of loan loss provisions to net loans; } A D Z=Z \text {-score; ADZP } \\
=\text { "ZP-score"; ADZP } 1=\text { measure of bank portfolio risk; ADZP } P_{2}=\text { measure of leverage } \\
\text { risk. }\end{array}$} \\
\hline
\end{tabular}


Table A.4. Rank correlation test: product diversification and level of risk and insolvency market measures for European listed banks (1996-2002)

\begin{tabular}{|c|c|c|c|c|c|}
\hline & \multicolumn{3}{|c|}{ Risk Measures } & \multicolumn{2}{|c|}{ Insolvency risk measures } \\
\hline & SDRET & BETA & RSPEC & MDZ & DD \\
\hline \multicolumn{6}{|l|}{ NNII } \\
\hline \% Rank Cor. & 37.84 & 33.68 & 33.16 & -33.53 & -29.47 \\
\hline $\begin{array}{l}\text { Spearman Stat. } \\
\text { Significance }\end{array}$ & 4.71 & 4.19 & 4.13 & -4.17 & -3.63 \\
\hline level $(\%)$ & $0.00 * * *$ & $0.00 * * *$ & $0.00 * * *$ & $0.00 * * *$ & $0.03 * * *$ \\
\hline \multicolumn{6}{|l|}{ COM } \\
\hline$\%$ Rank Cor. & 31.02 & 25.82 & 30.06 & -27.92 & -26.90 \\
\hline $\begin{array}{l}\text { Spearman Stat. } \\
\text { Significance }\end{array}$ & 3.85 & 3.20 & 3.73 & -3.47 & -3.31 \\
\hline level $(\%)$ & $0.01 * * *$ & $0.14 * * *$ & $0.02 * * *$ & $0.05 * * *$ & $0.09 * * *$ \\
\hline \multicolumn{6}{|l|}{$T R A D$} \\
\hline \% Rank Cor. & 17.05 & 29.27 & 9.09 & -15.42 & -26.15 \\
\hline $\begin{array}{l}\text { Spearman Stat. } \\
\text { Significance }\end{array}$ & 1.98 & 3.40 & 1.06 & -1.79 & -3.02 \\
\hline level $(\%)$ & $4.76^{* *}$ & $0.07 * * *$ & 29.09 & $7.32 *$ & $0.26 * * *$ \\
\hline \multicolumn{6}{|c|}{$\begin{array}{l}\text { Tstatistics test for the null:"Risk/Insolvency is not higher for high level of product diversification". } \\
* * *, * * \text { and } * \text { indicate significance respectively at the } 1 \%, 5 \% \text { and } 10 \% \text { levels for a unilateral test. } \\
\text { Variable definitions: NNII = ratio of net non interest income to net operating income; COM = ratio of } \\
\text { net commission income to net operating income; TRAD = ratio of net trading income to net operating } \\
\text { income; SDRET = standard deviation of daily returns; BETA = market model beta; RSPEC }= \\
\text { standard deviation of the market model residual; } M D Z=\text { market data based Z-score; DD = distance } \\
\text { to default. }\end{array}$} \\
\hline
\end{tabular}

